\title{
Review
}

\section{Role of Fluid Biomarkers and PET Imaging in Early Diagnosis and its Clinical Implication in the Management of Alzheimer's Disease}

\author{
Shahul Hameed ${ }^{\mathrm{a}, \mathrm{b}, *}$, Jong-Ling Fuh ${ }^{\mathrm{c}, \mathrm{d}}$, Vorapun Senanarong ${ }^{\mathrm{e}}$, Esther Gunaseli M. Ebenezer ${ }^{\mathrm{f}}$, \\ Irene Looi ${ }^{\mathrm{g}, \mathrm{h}}$, Jacqueline C. Dominguez ${ }^{\mathrm{i}}$, Kyung Won Park ${ }^{\mathrm{j}}$, Ananda Krishna Karanam ${ }^{\mathrm{k}}$ \\ and Oliver Simon ${ }^{1}$ \\ ${ }^{a}$ Department of Neurology, National Neuroscience Institute, Singapore General Hospital, Singapore \\ ${ }^{\mathrm{b}}$ Duke NUS Medical School, Singapore \\ ${ }^{\mathrm{c}}$ Department of Neurology, Neurological Institute, Taipei Veterans General Hospital, Taipei, Taiwan \\ ${ }^{\mathrm{d}}$ Faculty of Medicine, National Yang-Ming University School of Medicine, Taipei, Taiwan \\ e Division of Neurology, Faculty of Medicine, Siriraj Hospital, Mahidol University, Bangkok, Thailand \\ ${ }^{\mathrm{f}}$ Faculty of Medicine, University Kula Lumpur, Royal College of Medicine Perak, Ipoh, Malaysia \\ ${ }^{\mathrm{g}}$ Clinical Research Centre, Hospital Seberang Jaya, Penang, Malaysia \\ ${ }^{\mathrm{h}}$ Department of Medicine, Hospital Seberang Jaya, Penang, Malaysia \\ i Institute for Neurosciences, St. Luke's Medical Center, Metro Manila, Philippines \\ ${ }^{\mathrm{j}}$ Department of Neurology and Cognitive Disorders and Dementia Center, Institute of Convergence Bio-Health, \\ Dong-A University College of Medicine, Busan, Republic of Korea \\ ${ }^{\mathrm{k}}$ Novartis Healthcare Private Limited, Hyderabad, India \\ ${ }^{1}$ Novartis (Singapore) Pte. Ltd., Singapore, Singapore
}

Accepted 3 January 2020

\begin{abstract}
Clinical diagnosis of Alzheimer's disease (AD) is based on symptoms; however, the challenge is to diagnose AD at the preclinical stage with the application of biomarkers and initiate early treatment (still not widely available). Currently, cerebrospinal fluid (CSF) amyloid- $\beta 42\left(\mathrm{~A} \beta_{42}\right)$ and tau are used in the clinical diagnosis of $\mathrm{AD}$; nevertheless, blood biomarkers $\left(\mathrm{A} \beta_{42}\right.$ and tau $)$ are less predictive. Amyloid-positron emission tomography (PET) imaging is an advancement in technology that uses approved radioactive diagnostic agents (florbetapir, flutemetamol, or florbetaben) to estimate A $\beta$ neuritic plaque density in adults with cognitive impairment evaluated for $\mathrm{AD}$ and other causes of cognitive decline. There is no cure for $\mathrm{AD}$ to date-the disease progression cannot be stopped or reversed; approved pharmacological agents (donepezil, galantamine, and rivastigmine; memantine) provide symptomatic treatment. However, the disease-modifying therapies are promising; aducanumab and CAD106 are in phase III trials for the early stages of AD. In conclusion, core CSF biomarkers reflect pathophysiology of AD in the early and late stages; the application of approved radiotracers have potential in amyloid-PET brain imaging to detect early AD.
\end{abstract}

Keywords: Alzheimer's disease, biomarker, blood, cerebrospinal fluid, early diagnosis, positron emission tomography

\footnotetext{
${ }^{*}$ Correspondence to: Shahul Hameed, National Neuroscience Institute, Department of Neurology, Singapore General Hospital,
} 


\section{INTRODUCTION}

Dementia is a progressive heterogeneous syndrome leading to cognitive decline $[1,2]$, thereby interfering with individuals' abilities to perform daily activities independently [3] and affecting their quality of life [4]. According to Alzheimer's Disease International [5], an estimated 46.8 million people lived with dementia in 2015 (Asia: 22.9 million, Europe: 10.5 million, United States: 9.4 million, and Africa: 4.0 million), and this number is expected to increase to 131.5 million by 2050 . Dementia is overwhelming for patients, family members as well as their caregivers, and there is a need for healthcare professionals to raise awareness among caregivers and improve the quality of care for patients [6]. Currently, the symptomatic treatment of patients with dementia preserves functional independence, thereby improving their quality of life [7]. The total estimated economic cost of dementia worldwide is US\$ 817.9 billion, representing $1.09 \%$ of the global gross domestic product [5]. With advances in technology, the diagnosis of dementia at early stages and early therapeutic intervention could reduce the health and social care costs.

Alzheimer's disease (AD) is a multifactorial neurodegenerative disorder [8] and the leading cause of dementia in older individuals $[9,10]$. Other common types of dementia include: vascular dementia [11, 12], Parkinson's disease dementia [13, 14], Lewy body dementia $[15,16]$, and frontotemporal dementia $[17,18]$. The continuum of $\mathrm{AD}$ covers progression of disease from the asymptomatic to symptomatic phases (cognitive decline), through a preclinical phase identified by biomarkers that detect underlying neuropathophysiologic changes without clinical manifestations [19]. Clinically, AD is characterized by a progressive decline in the cognitive function [20] that interferes with the daily activities [21]. In $A D$, the cognitive impairment is a result of the neuronal cell death $[22,23]$, and mainly due to the loss of the neocortical synapses involved in cognition [24]. A major known risk factor for dementia due to $\mathrm{AD}$ is the advancing age [25], whereas another important risk factor is the apolipoprotein $\mathrm{E}(A P O E)$ $\varepsilon 4$ genotype [26]. Worldwide, an older population with an age of $\geq 65$ years is increasing from an estimated 617.1 million in 2015 (total world population of 7.3 billion) to 998.7 and 1,565.8 million in 2030 (total world population: 8.3 billion) and 2050 (total world population: 9.4 billion), respectively; the population aged $\geq 65$ years will rise with once a year average increase of 27.1 million from 2015 to 2050 [27]. One of the reasons for an increasing older population could be an improvement in life expectancy, which in turn increases the incidence of AD. Family members and caregivers play a critical role in maintaining the quality of life and improving the care of individuals living with AD dementia [28].

Currently, the amyloid cascade hypothesis and tau hypotheses are recognized in the pathogenesis of $A D$ [29]. The amyloid- $\beta(A \beta)$ peptide and tau (an axonal protein) are well-established predictors in AD pathogenesis [30]. The neuropathological hallmark of $\mathrm{AD}$ is the extracellular $\mathrm{A} \beta$ protein fragment (plaques) accumulation outside of the neurons and aggregation of the tau protein (tangles) within the neurons $[31,32]$. According to the $A \beta$ cascade hypothesis [31], the imbalance in the metabolism of amyloid- $\beta$ protein precursor (A $\beta P P$ ) results in monomeric $A \beta$ through proteolytic processing by the $\beta$-site A $\beta P P$ cleaving enzyme-1 (BACE1) within the endosomes and by intramembrane processing by $\gamma$-secretase [33]. The potential therapeutic strategy is, therefore, to decrease $A \beta$ peptide formation [34-36]. Further, the $A \beta$ monomers misfold and aggregate resulting in an abnormal elevation of $A \beta$ oligomers $[37,38]$ accumulating outside of the neuron that could trigger a cascade of cellular events, including hyperphosphorylation of tau (p-Tau) [39] accompanied by mitochondrial dysfunction [40, 41]. According to the mitochondrial cascade hypothesis, the dysfunction of mitochondria leads to the formation of $A \beta$ plaques, neurofibrillary tangles, synaptic degradation, and neuronal apoptosis in the late-onset, sporadic AD [42-44]. The Translocase of Outer Mitochondrial Membrane 40 (TOMM40) gene affects the mitochondrial dysfunction cascade in AD. TOMM40, located on human chromosome 19 (5'-upstream of the $A P O E$ gene), has received increasing attention as a promising $\mathrm{AD}$ biomarker. TOMM40 regulates $\mathrm{A} \beta$ influx into mitochondria independently or by interacting with APOE-dependent mechanisms, resulting in the cell to undergo downstream apoptotic processes through reactive oxygen species generation [45]. In addition, persistent neuroinflammation plays a key role in $\mathrm{AD}$ pathogenesis as well as progression [46, 47]. In-depth understanding of the molecular mechanism could help identify new disease-modifying therapies (DMTs).

To date, limited knowledge is available regarding the pathogenesis of $\mathrm{AD}$. The success of preventive strategies relies on understanding the time-course of $\mathrm{AD}$ and identifying individuals at risk of $\mathrm{AD}$ at 
the earliest stages (who have no significant signs of neurodegeneration) with the application of sensitive biomarkers. The challenge, however, remains with screening individuals at risk for $\mathrm{AD}$ prior to the onset of cognitive decline during the "preclinical" stages where there is a greater potential for the use of DMTs. This paper, therefore, aims to review the role of biomarkers in early diagnosis and its clinical implication in the management of $\mathrm{AD}$; the pharmacological treatment options are summarized. A literature search of English language articles on "Alzheimer's Disease", "biomarkers" and "treatment" through electronic databases (PubMed or Ovid) published before November 2019 was performed. Additional searches were performed through the clinical trial registry (ClinicalTrials.gov) for unpublished studies. Studies identified during the literature search were assessed for relevance based on the titles, abstracts, and/or the full text of the retrieved articles.

\section{ALZHEIMER'S DISEASE DIAGNOSTIC CRITERIA AND BIOMARKER CLASSIFICATION SYSTEM}

In 1984, the National Institute of Neurological and Communicative Disorders and Stroke and the Alzheimer's Disease and Related Disorders Association (NINCDS-ADRDA) developed criteria for the clinical diagnosis of $\mathrm{AD}$ based on clinicopathologic correlations [48]. The criteria included "probable $\mathrm{AD}$ " and "possible AD" (diagnosed clinically), and "definite AD" confirmed upon neuropathological investigations. The probabilistic AD diagnosis is within the clinical context with no definitive biomarker for diagnosis. In 2013, the American Psychiatric Association published the 5th edition of the Diagnostic and Statistical Manual of Mental Disorders [49] and introduced the new term "neurocognitive disorders". Although "dementia" is a "major neurocognitive disorder" according to DSM5 , the current diagnostic term "dementia" is an acceptable alternative [50]. The DSM-5 characterizes "major neurocognitive disorder" as a disturbance in one or more cognitive domains [50]: complex attention; executive function; learning and memory; language; perceptual-motor function; and social cognition. For major neurocognitive disorders due to $\mathrm{AD}$, there should be a decline in at least two cognitive domains (one should be learning and memory) according to the DSM-5 criteria, whereas the learning and memory deficit is sufficient for the diagnosis of mild neurocognitive disorders due to AD. The DSM5 criteria are designed for clinicians and focus on the clinical diagnosis. The clinical diagnosis of $\mathrm{AD}$ is usually after the onset of symptoms, by which point most neurons are affected; the goal is, therefore, to diagnose before the onset of clinical symptoms.

The recent paradigm shift in diagnosis helps the early detection of AD before the occurrence of clinical symptoms. The International Working Group (IWG) criteria [51-54] allows more accurate diagnosis of AD than the NINCDS-ADRDA criteria, even at the prodromal stage. This new diagnostic framework (defined as a dual clinicobiological entity) has shifted towards neurobiological measures of $\mathrm{AD}$. The diagnosis is achieved using the clinical manifestations of $\mathrm{AD}$ as well as via confirmation of $\mathrm{AD}$ pathology in vivo through biomarkers (pathophysiological and topographical markers) [52]. According to the IWG criteria, preclinical AD includes both an "asymptomatic at-risk state for $\mathrm{AD}$ " and "presymptomatic AD", whereas "prodromal AD" includes a symptomatic pre-dementia phase of $\mathrm{AD}$ (mild cognitive impairment [MCI] category) [51-54].

The National Institute on Aging-Alzheimer's Association (NIA-AA) workgroup proposed a diagnostic conceptualization of $\mathrm{AD}$ that will allow for the most effective DMT [55]. The criteria focus on the AD pathophysiological continuum with distinct cognitive staging [55-57]. The NIA-AA research framework defines $\mathrm{AD}$ biologically to recognize the disease progression that leads to cognitive impairment [56]. The NIA-AA classifies individuals with $\mathrm{AD}$ in to "probable AD dementia", "possible AD dementia", and "probable or possible AD dementia" with evidence of the AD pathophysiological processes [57]. The term "mild cognitive impairment due to AD" was used to refer to the symptomatic predementia phase of AD [58]. Preclinical AD precedes MCI, and screening for individuals with preclinical AD thereby provides an opportunity for DMT to change the course of the disease and evaluate the application of novel biomarkers. The preclinical AD stages include "asymptomatic cerebral amyloidosis"; "amyloid positivity plus evidence of synaptic dysfunction and/or early neurodegeneration"; and "amyloid positivity and neurodegeneration plus cognitive decline" [59]. The NIA-AA and IWG use biomarkers for the diagnosis of $\mathrm{AD}$, in contrast to the NINCDS-ADRDA criteria. Both NIA-AA and IWG criteria use similar terminology to define the AD continuum: "preclinical AD", "MCI due to AD" 
(NIA-AA) or "prodromal AD" (IWG) and "AD dementia" [60].

Finally, A/T/N is a binary classification system [61] related to biomarkers, which differentiates p-Tau and total $(\mathrm{t})$-Tau. There are 7 major AD biomarkers divided into 3 binary categories (each rated positive or negative) based on pathophysiology. "A" corresponds with the $A \beta$ biomarker (amyloid positron emission tomography [PET] or CSF A $\left.\beta_{42}\right)$, "T" corresponds with the tau pathology biomarker (CSF p-Tau or tau PET), and "N" corresponds with the quantitative or topographic biomarker of neurodegeneration or neuronal injury (CSF t-Tau, fluorodeoxyglucose (FDG)-PET, or structural MRI).

\section{APOE E4 GENE VARIANT AS A RISK FACTOR FOR ALZHEIMER'S DISEASE}

In humans, the $A P O E$ gene allelic variants include $\varepsilon 2, \varepsilon 3$, and $\varepsilon 4$ of which the $A P O E \varepsilon 4$ allele is the prevalent risk factor that is related to AD. Individuals with two copies of the APOE $\varepsilon 4$ allele have an increased risk of developing AD (12-fold) compared with those with 1 copy (3-fold) [62]. The association between $A P O E \& 4$ and the incidence of $\mathrm{AD}$ has been demonstrated in many populationbased studies. The results from a meta-analysis [63] showed a stronger association between the APOE genotype and $\mathrm{AD}(\varepsilon 3 / \varepsilon 4$ : odds ratio [OR], $5.6 ; \varepsilon 4 / \varepsilon 4$ : OR, 33.1) in Japanese subjects compared with Caucasians ( $\varepsilon 3 / \varepsilon 4$ : OR, 2.7 to $3.2, \varepsilon 4 / \varepsilon 4$ : OR, 12.5 to 14.9); however, the APOE $\varepsilon 4$ and $\mathrm{AD}$ association was weaker among African Americans $(\varepsilon 3 / \varepsilon 4$ : OR, $1.1 ; \varepsilon 4 / \varepsilon 4, \mathrm{OR}, 5.7)$ and Hispanics ( $\varepsilon 3 / \varepsilon 4$ : OR, 2.2; $\varepsilon 4 / \varepsilon 4$ : OR, 2.2). A systematic review [64] showed that $A P O E \& 4$ carrier frequencies varied, with the highest regional prevalence estimates in Northern Europe ( $84 /-: 61.3 \%, 95 \%$ confidence interval [CI] $55.9-66.7 ; \varepsilon 4 / 4: 14.1 \%, 95 \%$ CI $12.2-16.0)$ and the lowest regional estimates were in Asia ( $\varepsilon 4 /-:$ : $41.9 \%$, 95\%CI $38.5-45.3 ; \varepsilon 4 / \varepsilon 4: 7.7 \%$, 95\%CI $5.8-9.6)$ or Southern Europe/Mediterranean countries ( $\varepsilon 4 /-$ : $40.5 \%, 95 \%$ CI $36.8-44.1 ; \varepsilon 4 / \varepsilon 4$ prevalence: $4.6 \%$, 95\%CI 2.7-6.4). A meta-analysis [65] in the Chinese population showed a positive association between the $A P O E \& 4$ allele carriers and $\mathrm{AD}(\mathrm{OR}, 3.93 ; 95 \% \mathrm{CI}$ $3.37-4.58 ; p<0.00001)$. The carriers of the homozygous $A P O E \varepsilon 4 / \varepsilon 4$ and heterozygous $A P O E$ \& $4 / \varepsilon 3$ alleles have a significant association with AD (OR, 11.76 and 3.08, respectively; both $p<0.00001$ ). Generally, the prevalence of $\mathrm{AD}$ is higher in women possibly due to a longer life expectancy [66]. A meta-analysis [67] of 27 studies (57,979 participants), however, showed that both men and women with $A P O E \varepsilon 3 / \varepsilon 4$ genotype had similar risks of $\mathrm{AD}$ between 55 and 85 years of age (OR 3.09 and 3.31, respectively); whereas women had a higher risk of AD than men between 65 and 75 years (OR: 4.37 and 3.14, respectively). Studies have shown an association between the $\varepsilon 4$ allele and cognitive decline. From the Alzheimer's Disease Neuroimaging Initiative study, 399 subjects (cognitively normal $=109$, amnestic subjects with $\mathrm{MCI}=192, \mathrm{AD}=98$ ) were used to evaluate the effect of $A P O E \varepsilon 4$ on biomarkers of neurodegeneration [68]; the results showed a clear APOE $\varepsilon 4$ dose-dependent effect on CSF A $\beta_{1-42}$ levels within each clinical group. The results from a large multicenter study of 716 cognitively healthy individuals (aged 17-99 years) showed age-dependent effects of the APOE $\varepsilon 4$ allele on the onset of preclinical $\mathrm{AD}$ as $\mathrm{CSF} A \beta_{1-42}$ concentrations started to decline at 50 years of age in APOE $\varepsilon 4$ allele negative individuals, at 43 years of age in those carrying one $A P O E \& 4$ allele, and even earlier in individuals carrying $2 A P O E \varepsilon 4$ alleles [69]. The Generation Scotland: Scottish Family Health Study $(\mathrm{N}=18,337)$ showed the association of additive effects of $A P O E$ $\varepsilon 4$ with lower scores on logical memory $(\beta=-0.095$, $p=0.003)$, verbal fluency $(\beta=0.075, p=0.023)$, and digit symbol tests $(\beta=-0.087, p=0.004)$ in individuals aged $>60$ years [70]. Taken together, individuals who carry $A P O E \varepsilon 4$ allele may have increased risk of developing $\mathrm{AD}$, increased rate of age-dependent cognitive decline, and decreased memory performance compared with non-carriers. Currently, the clinical use of $A P O E \varepsilon 4$ genotyping is being tested and could be used to screen asymptomatic individuals, but is not recommended outside of research settings.

\section{BIOMARKERS FOR EARLIER DIAGNOSIS OF AD DEMENTIA}

According to Hulka and colleagues, biomarkers (biological markers) are "cellular, biochemical or molecular alterations that are measurable in biological media such as human tissues, cells, or fluids" [71]. Biomarkers provide insight into underlying mechanisms, disease progression, prognosis, regression, response to therapy, and accurate early diagnosis for early treatment [71]. Clinically, AD is diagnosed based on symptoms and the challenge is to diagnose $\mathrm{AD}$ at the preclinical stage with the application of 
biomarkers and initiate early treatment. The clinical diagnostics of AD are currently probabilistic. At present, the biomarkers are available in certain countries only, and the newer treatment options emerge for early $\mathrm{AD}$ and help in the definitive diagnosis.

\section{Fluid biomarkers (CSF and blood) for the clinical diagnosis of Alzheimer's disease}

The CSF is in contact directly with the extracellular spaces of the brain and the metabolism of proteins (e.g., $A \beta$ and tau) in the brain is therefore reflected within the CSF. Hence, $A \beta_{42}$, t-Tau, and p-Tau are the core biomarkers used as diagnostic tools in $\mathrm{AD}$ [72]. The results from a number of longitudinal studies have suggested that altered CSF $A \beta_{42}$ is predictive of AD. Studies have demonstrated that high levels of CSF tau and low CSF A $\beta_{42}$ are predictive of $A D$ and their application in the pre-dementia clinical studies could help to include suitable subjects for the assessment of treatment benefit against the risk. A study in patients with $(n=33)$ and without $(n=11)$ dementia of the Alzheimer's type showed that increased dementia severity was correlated with decreased concentrations of soluble $A \beta P P$ and $A \beta$ protein and increased CSF tau [73]. Results from a retrospective study [74] of 21 patients with probable $A D$ showed a significant decrease in the concentrations of CSF $A \beta_{42}(265 \pm 156$ versus $746 \pm 238 \mathrm{ng} / \mathrm{l})$ but an increase in t-Tau $(803 \pm 553$ versus $297 \pm 129 \mathrm{ng} / \mathrm{l})$ and p-Tau $(95.9 \pm 57.5$ versus $49.5 \pm 21.2 \mathrm{ng} / \mathrm{l}) \mathrm{com}$ pared with the control population (all $p<0.001$ ). During the 5- and 6-year follow-up, 8 out of 21 and 11 out of 21 patients who died had significantly lower levels of CSF A $\beta_{42}$ compared with those alive ((mean \pm standard deviation [SD] $170.6 \pm 80.7$ versus $323.6 \pm 164.1 \mathrm{ng} / \mathrm{l} ; p=0.011)$ and (mean $\pm \mathrm{SD}$ : $193.6 \pm 84.4$ versus $344.3 \pm 180.9 \mathrm{ng} / \mathrm{l} ; p=0.041)$, respectively). A follow-up study [75] (range: 4.0-6.8 years) showed that patients with $\mathrm{MCI}$ at baseline who developed AD (MCI-AD, $n=57$ ) had a significant decrease in CSF A $\beta_{42}$ (mean [SD] 324 [101] [MCI-AD] versus 700 [181] [controls] or 551 [188] ng/l [stable MCI], both $p<0.0001)$ and CSF A $\beta_{42} / \mathrm{p}$ $\mathrm{Tau}_{181}$ ratio compared with controls or those with stable MCI (mean [SD] 3.7 [1.6] [MCI-AD] versus 12.5 [4.7] [controls] or 9.5 [3.8] [stable MCI], both $p<0.0001$ ), whereas CSF p-Tau 181 (mean [SD] 95 [29] [MCI-AD] versus 61 [17] [controls] or 62 [16] ng/l [stable MCI], both $p<0.0001$ ) and CSF t-Tau (mean [SD] 816 [426] [MCI-AD] versus 326 [157] [controls] or 340 [212] ng/l [stable
MCI], both $p<0.0001$ ) significantly increased compared with controls or those with stable MCI. The study showed that pathological CSF was a strong risk factor for the development of $\mathrm{AD}$ with an adjusted hazard ratio [95\% CI] for t-Tau and $A \beta_{42}$ of $17.7(5.33-58.9 ; p<0.0001), \mathrm{CSF}$ p-Tau 181 and $\mathrm{A} \beta_{42}$ of 16.8 (5.02-56.5; $\left.p<0.0001\right)$, and $\mathrm{t}-\mathrm{Tau}$ and $\mathrm{A} \beta_{42} / \mathrm{p}-\mathrm{Tau}_{181}$ of $19.8(5.99-65.7 ; p<0.0001)$. Results from a two-part study (cross-sectional and prospective cohort studies; $N=750$ ) [76] showed that 330 patients progressed to clinical dementia from MCI and 420 of were on stable MCI for at least 2 years of follow-up. Of the 330 patients with MCI, 271 were diagnosed with $\mathrm{AD}$ and 59 with other dementias. Of the 271 patients with incipient $\mathrm{AD}$, the CSF $\mathrm{A} \beta_{42}$ levels were significantly lower than controls (median [range]: 356 [96-1075] versus 675 [182-1897] $\mathrm{ng} / \mathrm{l} ; p<0.001$ ), whereas the p-Tau and t-Tau levels were significantly higher than controls (median [range]: 81 [15-183] versus 51 [16-156] ng/l and 582 [83-2174] versus 280 [42-915] ng/l, respectively; both $p<0.001$ ). The positive and negative likelihood ratio values for $\mathrm{A} \beta_{42}$; p-Tau; and t-Tau were 2.3 (95\% CI 2.0-2.6) and 0.32 (95\% CI $0.28-0.36) ; 1.6$ (95\%CI, $1.4-1.8)$ and $0.34(95 \% \mathrm{CI}, 0.31-0.37)$; as well as $1.9(95 \% \mathrm{CI}$ $1.7-2.2)$ and 0.26 (95\%CI 0.23-0.29), respectively. The area under the receiver operating characteristic (ROC) curve for $A \beta_{42}$, p-Tau, and t-Tau was 0.78 (95\%CI $0.75-0.82), 0.76$ (95\%CI $0.72-0.80$ ), and 0.79 (95\% CI 0.76-0.83), respectively. In a crosssectional case-control study [77] Chinese patients $(\mathrm{N}=48)$ with $\mathrm{AD}$ had significantly higher levels of CSF tau (median [interquartile range] 660.22 [394.65] versus 224.61 [132.66] pg/ml) and p-Tau (78.13 [44.35] versus 35.53 [20.53] pg/ml) compared with non-demented controls (both $p<0.001$ ). Patients with AD had significantly lower CSF $\mathrm{A} \beta_{42}$ levels than non-demented controls (median [interquartile range] 278.11 [181.64] versus 458.90 [417.55] $\mathrm{pg} / \mathrm{ml} ; p=0.022$ ). Moreover, patients with $\mathrm{AD}$ had significantly lower $\mathrm{A} \beta_{42}-\mathrm{t}$-Tau (median [interquartile range] 0.442 [0.650] versus 3.12 [1.96]; $p<0.001)$ and $\mathrm{A} \beta_{42}-\mathrm{p}$-Tau ratios compared with non-demented controls (median [interquartile range] 3.69 [3.82] versus 19.54 [10.71]; $p<0.001)$. The results of the first study assessing the $A \beta_{42} / A \beta_{40}$ ratio [78] showed that patients with $\mathrm{MCI}$ at baseline who developed AD (MCI-AD, $n=57$ ) had a significant decrease in CSF $A \beta_{42} / A \beta_{40}$ ratio and $A \beta_{42}$ concentration than those with stable MCI or controls $\left(\mathrm{A} \beta_{42} / \mathrm{A} \beta_{40}\right.$ ratio: mean $\pm \mathrm{SD} 0.78 \pm 0.19$ [MCI- 
$\mathrm{AD}$ ] versus $1.3 \pm 0.66$ [stable $\mathrm{MCI}$ ] or $1.5 \pm 1.1$ [control], both $p<0.001 ; \mathrm{A} \beta_{42}: 0.46 \pm 0.12$ [MCI$\mathrm{AD}$ ] versus $0.67 \pm 0.26$ [stable $\mathrm{MCI}$ ] or $0.87 \pm 0.36$ [control] $\mathrm{ng} / \mathrm{ml}$, both $p<0.001)$. The AUC was significantly larger for the $A \beta_{42} / A \beta_{40}$ ratio compared with the $A \beta_{42}(0.87 ; 95 \% \mathrm{CI} 0.80-0.92$ versus $0.77 ; 95 \%$ CI $0.69-0.84 ; p<0.05)$. In a study (76 patients with $\mathrm{AD}$ dementia) of CSF biomarkers for $\mathrm{AD}$ in South Korea [79] the $A \beta_{42}$ levels were significantly lower in patients with $\mathrm{AD}$ dementia compared with controls and those with other neurological disorders (OND) (316.1 \pm 105.7 [AD] versus $676.0 \pm 175.1$ [control] and $565.8 \pm 187.9 \mathrm{pg} / \mathrm{ml}$ [OND]; $p<0.001)$; conversely there were higher t-Tau (583.0 $\pm 286.4[\mathrm{AD}$ ] versus $212.5 \pm 67.3$ [control] and $227.9 \pm 120.0 \mathrm{pg} / \mathrm{ml}[\mathrm{OND}] ; p<0.001)$ and p-Tau (73.8 \pm 28.8 [AD] versus $41.9 \pm 12.8$ [control] and $37.0 \pm 15.4 \mathrm{pg} / \mathrm{ml}[\mathrm{OND}] ; p<0.001)$ levels in patients with AD compared with controls and OND. The areas under the curve were more accurate for t-Tau $/ A \beta_{42}$ and $\mathrm{pTau} / \mathrm{A} \beta_{42}$ ratios: 0.99 (for both biomarker ratios) and 0.94 (for both biomarker ratios) for $\mathrm{AD}$ dementia versus control and $\mathrm{AD}$ dementia versus OND, respectively. Recently, a large, multicentric cohort study [80] $(\mathrm{N}=3565)$ assessed the relationship between CSF $A \beta_{42}$ and CSF tau. Of the 3565 patients, 947 had a normal biomarker levels (A-N-), 1299 had an $\mathrm{AD}$ profile $(A+\mathrm{N}+), 789$ patients were amyloid positive $(A+\mathrm{N}-)$, and 527 had the suspected non-AD pathophysiology profile positive for neurodegeneration (A-N+). The findings from this study showed that $36 \%$ of patients who were amyloid positive evolved to $\mathrm{AD}$ profile $(A+\mathrm{N}+)$.

Findings from a recent systematic review and meta-analysis [81] of fluid biomarkers (CSF and blood) showed $A D$ to control $A \beta_{42}$ ratios below one (except for one) with average ratio of 0.56 (AD patients $=9949$, controls $=6841)$ and AD to control ttau as well as p-tau ratios above one with average ratio of 2.54 (AD patients $=11341$, controls $=7086)$ and 1.88 (AD patients $=7498$, controls $=5126)$, respectively (all $p<0.0001$ ). These core biomarkers also differentiated between cohorts with MCI due to $\mathrm{AD}$ and those with stable MCI with an average ratio of 0.67 for $C S F A \beta_{42}(A D M C I=352$, stable $\mathrm{MCI}=610), 1.72$ for $\mathrm{p}$-tau $(\mathrm{AD} \mathrm{MCI}=307$, stable $\mathrm{MCI}=570)$, and 1.76 for $\mathrm{t}$-tau (AD MCI $=251$, stable $\mathrm{MCI}=501)$. Moreover, results from a meta-analysis (Version 2.1, June 2018) [82] showed lower CSF $\mathrm{A} \beta_{42}$ levels in patients with $\mathrm{AD}(\mathrm{N}=11,277)$ versus controls $(\mathrm{N}=8315)$ and lower baseline $\mathrm{CSF} A \beta_{42}$ levels in those with MCI to develop AD (MCI-AD
$\mathrm{N}=526)$ versus stable MCI (MCI-stable $\mathrm{N}=881$ ), with an overall effect size (weighted average of the individual effect sizes) of 0.559 and 0.663 , respectively (both $p<0.0001$ ). Conversely, CSF t-tau levels were higher in patients with $\mathrm{AD}(\mathrm{N}=12,503)$ versus controls $(\mathrm{N}=8145)$ and baseline CSF t-tau levels were higher in those with MCI to develop $\mathrm{AD}$ (MCI-AD N=481) versus stable MCI (MCI-stable $\mathrm{N}=841$ ), with an overall effect size of 2.480 and 1.730 , respectively (both $p<0.0001$ ). Although the CSF $A \beta_{42}$ and tau have sensitivity and specificity, there is a need for other biomarkers for early diagnosis of AD. Recently, results from a meta-analysis [83] (129 papers) showed that in early AD there was an increase in the levels of CSF t-tau as well as CSF p-tau and a decrease in CSF A $\beta_{42}$ levels. Currently, the diagnosis of $\mathrm{AD}$ is made from the clinical observation of cognitive decline; however, definitive $\mathrm{AD}$ is confirmed postmortem from microscopic observation of the brain tissue.

Novel biomarkers available in clinical samples such as blood are being discovered for the early diagnosis of AD. However, studies have shown that the free blood plasma $A \beta$ is less predictive for the clinical diagnosis of $A D$ and there is no correlation between the blood and CSF $A \beta_{42}$ concentrations $[84,85]$. Plasma tau as a biomarker for the clinical diagnosis of $\mathrm{AD}$ is not supported as the correlations between high plasma tau as well as higher CSF tau and lower CSF A $\beta_{42}$ were mild and differed between cohorts [86]. In addition, results from a meta-analysis (Version 2.1, June 2018) [82] showed no difference in plasma $A \beta_{42}$ in patients with $\mathrm{AD}(\mathrm{N}=2336)$ versus controls $(\mathrm{N}=4452)$ and did not differ in baseline plasma $A \beta_{42}$ levels in those with MCI to develop AD (MCI-AD N =308) versus stable $\mathrm{MCI}$ (MCI-stable $\mathrm{N}=379$ ), with an overall effect size (weighted average of the individual effect sizes) of $1.031(p=0.38718)$ and 0.807 $(p=0.32403)$, respectively. Conversely, plasma levels of $\mathrm{t}$-tau were higher in patients with $\mathrm{AD}(\mathrm{N}=447)$ versus controls $(\mathrm{N}=552)$ with an overall effect size of $1.788(p=0.00550)$, with considerable variability in the studies. Recently, immunoprecipitation and mass spectrometry techniques have been used to measure levels of high-performance plasma $A \beta$ biomarkers in the blood [87]. The results showed that $\mathrm{A} \beta P P 669-711 / \mathrm{A} \beta_{1-42}$ and $\mathrm{A} \beta_{1-40} / \mathrm{A} \beta_{1-42}$ ratios as well as their composites are clinically useful plasma biomarkers. However, there is a need for other noninvasive biomarkers to detect $\mathrm{AD}$ and sensitive techniques to measure such proteins at low 
concentrations. Recently, plasma neurofilament light (NFL) is proposed as a blood-based biomarker, and studies have suggested its potential to predict the course of AD. A highly sensitive technology, the single-molecule array (Simoa) platform was used to measure the plasma NFL to assess its application as a noninvasive biomarker to detect $\mathrm{AD}$ [88]. The results from this prospective case-control study (cognitively healthy controls $=193, \mathrm{MCI}=197$ patients, $A D$ with dementia $=180$ patients) showed that there was a correlation between plasma NFL and CSF NFL (Spearman $\rho=0.59, p<0.001$ ). Compared with controls (mean, $34.7 \mathrm{ng} / \mathrm{l}$ ) there was increase in plasma NFL in patients with MCI (mean, $42.8 \mathrm{ng} / \mathrm{l}$ ) and patients with $\mathrm{AD}$ dementia (mean, $51.0 \mathrm{ng} / \mathrm{l}$ ) $(p<0.001)$. Although high plasma NFL levels were associated with cognitive decline, there was no difference in plasma NFL levels between $A \beta$-positive patients with progressive MCI and those with stable MCI. Moreover, findings from a recent study [89] showed that plasma NFL levels were significantly different across the diagnostic groups: AD $(50.9 \mathrm{pg} / \mathrm{ml})$ $>$ amnestic MCI $(43.0 \mathrm{pg} / \mathrm{ml})>$ cognitively normal (34.7 pg/ml) (all $p<0.001)$, but with substantial overlap thereby limiting its application as a diagnostic biomarker. A prospective study [90] of women $(\mathrm{N}=5309)$ from the prospective epidemiological risk factor study showed the high levels of Tau-A and Tau-C (truncated tau) biomarkers in the serum were associated with a lower risk of AD (Tau-A: HR [95\% CI] 0.71 [0.52-0.98]; Tau-C: 0.78 [0.60-1.03]). Recently, a study using immuno-infrared assay [91] showed the ability of amide I blood biomarker to detect $\mathrm{AD}$ on average 8 years before onset of the clinical symptoms (ESTHER study). The assay distinguished AD from controls with a sensitivity of $71 \%$ and specificity of $91 \%$ for ESTHER study and a sensitivity of $69 \%$ and specificity of $86 \%$ for the BioFINDER study. Recently, a study using Quanterix Simoa-HD1 tau platform [92] showed that the plasma pTau181 was a more sensitive and specific predictor of elevated brain $A \beta$ than total tau, and that plasma pTau $_{181}$ may be used as a biomarker of AD pathology. A study of two-step immunoassay that measured concentration of $A \beta_{38}, A \beta_{40}$, and $A \beta_{42}$ in the human blood plasma showed that $A \beta_{42} / A \beta_{40}$ ratio is promising biomarker candidate of $\mathrm{AD}$ [93]. The areas under the ROC curves were 0.87 and 0.80 for the $A \beta_{42} / A \beta_{40}$ ratio and $A \beta_{42} / A \beta_{38}$ ratio, respectively. A study quantified plasma t-tau, p-tau, and $A \beta_{1-42}$ in 76 patients (cognitively normal, $n=52$; MCI, $n=9$; $\mathrm{AD}$ dementia, $n=15$ ) and examined the degree of brain tau deposition as observed using tau-PET [94]. The study showed that in plasma t-tau/A $\beta_{1-42}$ ratio was highly predictive of brain tau deposition, with high t-tau/amyloid- $\beta_{1-42}$ AUC value of 0.890 (sensitivity, 80\%; specificity, 91\%) than 0.802 for ttau (sensitivity, 93\%; specificity, 63\%) or 0.766 for plasma p-tau/A $\beta_{1-42}$ (sensitivity, 93\%; specificity, $51 \%$ ) or 0.731 for plasma p-tau (sensitivity, 93\%; specificity, 49\%). A study used immunoprecipitation and liquid chromatography-mass spectrometry assay measured the levels of plasma and CSF of $A \beta_{42} / A \beta_{40}$ in cognitively normal individuals $(\mathrm{N}=158)$ [95]. The study provided class II evidence that plasma $\mathrm{A} \beta_{42} / \mathrm{A} \beta_{40}$ was predictive of the brain amyloidosis, with area under the ROC curves of 0.88 and high correspondence with CSF p-tau181/A $\beta_{42}$ (AUC $0.85)$. Recently, findings from a study using Elecsys immunoassays (BioFINDER cohort, $n=842$; independent validation cohort, $n=237$ ) showed the area under the ROC curve of 0.80 for plasma $A \beta_{42}$ and $\mathrm{A} \beta_{40}$ to predict $A \beta$ positivity in BioFINDER compared with 0.86 in the independent validation cohorts [96]. Currently there are no validated blood-based biomarkers for $\mathrm{AD}$ in clinical use. The advantage of blood-based biomarkers is that they are less invasive and more cost-effective than the CSF biomarkers (which involve lumbar puncture and CSF collection); however, the advent of new techniques could enable early diagnosis of $\mathrm{AD}$, effectively screen patient populations, and measure treatment effect in the clinical studies.

\section{PET imaging biomarkers (A $\beta$-PET and tau PET) for clinical diagnosis of Alzheimer's disease}

The A $\beta$-PET is a molecular imaging tool that uses radiotracers to picture the accumulation of $A \beta$ plaque within an $\mathrm{AD}$ brain and monitors disease progression. At the moment, A $\beta$-PET imaging or measuring CSF $A \beta$ levels are the available options for the clinical diagnosis of $A \beta$ deposition in AD. Florbetapir [97] (Amyvid ${ }^{\mathrm{TM}}$ ) was the first approved radioactive diagnostic agent followed by Flutemetamol [98] (Vizamyl $^{\mathrm{TM}}$ ) and Florbetaben [99] (NeuraCeq ${ }^{\mathrm{TM}}$ ) indicated for PET imaging of the brain to estimate the density of $A \beta$ neuritic plaque in adults with cognitive impairment who are being evaluated for $\mathrm{AD}$ and other causes of cognitive decline. Florbetapir F 18 is a sterile, non-pyrogenic radioactive diagnostic agent that binds to $A \beta$ aggregates. Results from the first phase III study $(\mathrm{N}=152)$ [100] showed good correlation (primary analysis cohort 
of 29 patients) between the whole brain florbetapirPET visual image scores and cortical $A \beta$ pathology at autopsy as measured by immunohistochemistry (Bonferroni $\rho, 0.78$ [95\%CI 0.58-0.89]; $p<0.001$ ) and silver stain neuritic plaque score (Bonferroni $\rho$, 0.71 [95\%CI 0.47-0.86]; $p<0.001$ ). Moreover, the prospective cohort study (59 primary analysis participants) [101] for patients who had autopsies within 2 and 1 years of cerebral PET imaging with florbetapir to detect moderate to frequent neuritic $A \beta$ plaques showed a sensitivity of $92 \%$ (36 out of 39; 95\%CI 78-98) and 96\% (27 of 28; 95\%CI 80-100), respectively, as well as a specificity of $100 \%$ (20 out of 20; 95\%CI 80-100) and $100 \%$ (18 out of 18 ; 95\%CI 78-100), respectively. This study distinguished patients with moderate to frequent plaques (A $\beta$ positive) from those with no or sparse plaques (A $\beta$ negative). Flutemetamol F18 is a sterile, nonpyrogenic, radioactive diagnostic agent that binds to $A \beta$ aggregates. Results from the phase III study $(\mathrm{N}=176 ; 68$ evaluable brains: $37 \% \mathrm{~A} \beta$ negative and $63 \% \mathrm{~A} \beta$ positive) [102] showed high sensitivity without computed tomography of $81 \%-93 \%$ (median, 88\%; majority, 86\%) and high specificity of $44 \%-92 \%$ (median, $88 \%$; majority, $92 \%$ ) to detect neuritic $A \beta$ plaque with PET imaging using $\left[{ }^{18} \mathrm{~F}\right]$ flutemetamol. Florbetaben F18 is a sterile, nonpyrogenic radioactive diagnostic agent that binds to $\mathrm{A} \beta$ aggregates. Results from a pivotal histopathology phase III study $(\mathrm{N}=216 ; 74$ deceased subjects, 46 out of $47 \mathrm{~A} \beta$ positive; 24 out of $27 \mathrm{~A} \beta$ negative) [103] showed high sensitivity of $97.9 \%$ (95\%CI 93.8-100) and specificity of $88.9 \%$ (95\%CI 77.0-100) to detect neuritic $A \beta$ plaques with the visual analysis consistent with quantitative assessment using florbetaben PET (sensitivity: 89.4\% [95\%CI 80.6-98.2] and specificity: 92.3\% [95\%CI 82.1-100]). The amyloid load in an AD brain can be measured using PET, which has played a key role in clinical diagnosis.

Tau PET imaging is sensitive and detects early cognitive changes in the preclinical AD than $A \beta$ PET imaging [104, 105]. Although tau PET imaging provides novel insights into AD progression, there are several challenges because tau proteins form intracellular aggregates (tangles) [106] and radiotracers for these proteins have to cross the blood-brain barrier [107]; moreover, tau proteins undergo posttranslational modifications [108] and available in six isoforms [109]. Efforts are ongoing to develop specific radiotracers for tau PET imaging [110]. Currently, tau radiotracers are not available for clinical use, and so far $\left[{ }^{18} \mathrm{~F}\right]$ flortaucipir (Avid Radiophar-
maceuticals/Eli Lilly) is the most validated tau PET radiotracer. A cross-sectional study [111] in 719 patients $(n=179, \mathrm{AD}$ dementia $[100 \% \mathrm{~A} \beta$ positive]; $n=254$, non-AD neurodegenerative disorder [23.8\% A $\beta$ positive], $n=126$, MCI [65.9\% A $\beta$ positive]; $n=160$, cognitively normal controls $[26.3 \%$ $\mathrm{A} \beta$ positive]) had showed that the $\left[{ }^{18} \mathrm{~F}\right]$ flortaucipir PET had distinguish AD dementia from all non-AD neurodegenerative disorders in the medialbasal and lateral temporal cortex $(89.9 \%$ sensitivity and $90.6 \%$ specificity [SUVR 1.34]). A case study [112] was performed to validate the use of $\left[{ }^{18} \mathrm{~F}\right]$ flortaucipir PET to detect in vivo tau pathology in an individual with early onset AD (PSEN1 mutation). This study showed that in vivo retention of $\left[{ }^{18} \mathrm{~F}\right]$ flortaucipir was correlated with postmortem tau pathology in the $\mathrm{AD}$ brain: density of tau-positive neurites (AT8: $\mathrm{rs}=0.87 ; p<0.001$; Gallyas: $\mathrm{rs}=0.92$; $p<0.001$ ), intrasomal tau tangles (AT8: $\mathrm{rs}=0.65$; $p=0.01$; Gallyas: $r s=0.84 ; p<0.001)$ and total tau burden (AT8: rs $=0.84 ; p<0.001$; Gallyas: $r s=0.82$; $p<0.001$ ), but not with the $A \beta$ pathology. Recently, a small Phase III study [113] was performed in 156 patients (aged $\geq 50$ years) who had projected life expectancy of $\leq 6$ months and in those consented to brain donation at autopsy. This study assessed the relationship between antemortem $\left[{ }^{18} \mathrm{~F}\right]$ flortaucipir PET imaging and tau pathology in AD at autopsy. Of 156 patients who underwent $\left[{ }^{18} \mathrm{~F}\right]$ flortaucipir PET imaging, 67 were evaluated postmortem. In this study $\left[{ }^{18} \mathrm{~F}\right]$ flortaucipir demonstrated statistically significant sensitivity and specificity to detect tau pathology of Braak Stage V/VI and high level of total AD neuropathologic change as defined by NIA-AA criteria [114].

\section{PHARMACOLOGICAL SYMPTOMATIC TREATMENT FOR ALZHEIMER'S DISEASE AND UPCOMING DISEASE-MODIFYING THERAPIES}

\section{Symptomatic treatment for Alzheimer's disease}

The cholinergic hypothesis has yielded approved drugs for treating $\mathrm{AD}$ and has been pivotal for studies in dementia. According to the cholinergic hypothesis [115], the degeneration of cholinergic neurons and a decrease in cholinergic neurotransmission in the brain leads to cognitive deficits in patients with $\mathrm{AD}$. At present, there is no cure for $\mathrm{AD}$ and the progression of the disease cannot be stopped or reversed; however, pharmacolog- 
ical treatment (cholinesterase inhibitors [ChEIs] [116] and N-methyl-D-aspartate [NMDA] receptor antagonists [117]) provides symptomatic relief [2]. Current symptomatic AD treatment options approved by the US Food and Drug Administration include the ChEIs donepezil, galantamine, and rivastigmine as well as the NMDA receptor antagonist, memantine. The ChEIs donepezil and galantamine have acetylcholinesteraseinhibiting activity; whereas rivastigmine is a dual acetylcholinesterase-butyrylcholinesterase inhibitor [118]. Although the current pharmacological drug options provide symptomatic improvement, there is a need for treatment at the presymptomatic phase of the disease with disease-modifying effects.

In the brain of a patient with $\mathrm{AD}$, there is a decrease in acetylcholine levels. A strategy to treat $\mathrm{AD}$ is inhibiting ChEI to hydrolyze the neurotransmitter acetylcholine into choline at the cholinergic synapses resulting in increased brain acetylcholine levels and leading to cognitive benefits of treatment compared with placebo. Donepezil (Aricept ${ }^{\circledR}$ ) is a reversible acetylcholinesterase inhibitor indicated for the treatment of mild, moderate, and severe AD [119]. In the double-blind, randomized controlled studies there were improvements in cognition as measured by the Alzheimer's Disease Assessment Scale-Cognitive subscale (ADAS-Cog) in patients with $\mathrm{AD}$ treated with donepezil compared with those who received placebo [120-122]. Galantamine (Razadyne $\mathrm{ER}^{\circledR}$ and Razadyne ${ }^{\circledR}$ ) is a competitive reversible acetylcholinesterase inhibitor indicated for the treatment of mild-to-moderate dementia of the Alzheimer's type [123]. Doubleblind, randomized controlled studies in patients with AD showed improvements in cognition as measured by ADAS-Cog in those treated with galantamine compared with placebo [124-127]. Rivastigmine is a reversible ChEI available as a capsule $\left(\right.$ Exelon $^{\circledR}$ ) or patch (Exelon Patch ${ }^{\circledR}$ ). Oral rivastigmine is indicated for the treatment of mild-to-moderate dementia of the Alzheimer's type [128], whereas transdermal rivastigmine is indicated for mild, moderate, and severe dementia of the Alzheimer's type [129]. Rivastigmine is also indicated for mild-to-moderate dementia associated with Parkinson's disease [128, 129]. In the brain of $A D$ patients there is a decrease in acetylcholine levels, and rivastigmine increases brain acetylcholine levels by dual inhibition of acetylcholinesterase-butyrylcholinesterase, which is responsible for acetylcholine hydrolysis [118]. In double-blind, randomized controlled studies improvements in cognition as measured by ADASCog were observed in patients with $\mathrm{AD}$ treated with rivastigmine compared with those who received placebo [130, 131]. Glutamate is the main excitatory neurotransmitter that activates NMDA receptors of the central nervous system contributing to $\mathrm{AD}$ symptoms. Memantine uncompetitively binds to the NMDA receptor open-channel with moderate affinity and to exert its therapeutic effect. Memantine is an orally active NMDA receptor antagonist indicated for the treatment of moderate to severe dementia of the Alzheimer's type [132]. Results from the doubleblind, randomized controlled studies in patients with AD showed improvements in cognition as measured by ADAS-Cog in those treated with memantine compared with placebo [133, 134]. Generally, in AD clinical studies cognitive change in patients with $\mathrm{AD}$ is measured using ADAS-Cog, which is a standard primary outcome where the cognitive defect is severe. However, in the early stages of AD (prodromal) there is a mild decline in cognition, and these changes are difficult to measure. Recently, a new sensitive outcome measure, the AD Composite Score (ADCOMS) was developed to assess the cognitive decline in early $\mathrm{AD}$ trials and detect treatment effects [135].

Recently a meta-analysis [136] was performed (36 studies) including 6611 patients with $\mathrm{AD}$ to assess the efficacy and safety of donepezil, galantamine, rivastigmine, and memantine in symptomatic AD treatment. Results showed significant changes in cognition with active treatment versus placebo. The changes in cognition as assessed by ADAS-cog showed standardized mean differences of -0.28 (95\% CI $[-0.39,-0.16], p<0.00001)$, $-0.49(95 \% \mathrm{CI}[-0.56,-0.43] ; p<0.00001],-0.65$ $(95 \% \mathrm{CI}[-1.06,-0.23] ; p=0.002)$ and $-0.12(95 \% \mathrm{CI}$ $[-0.24,-0.01], p=0.03)$ for donepezil, galantamine, rivastigmine, and memantine, respectively. The findings from meta-analysis showed delay for at least 52 weeks in the progression of cognitive impairment in patients with $\mathrm{AD}$ treated with symptomatic treatment with ChEIs (donepezil, rivastigmine, galantamine) and $\mathrm{N}$-methyl-D-aspartate receptor antagonist (memantine).

\section{Upcoming disease-modifying therapies for Alzheimer's disease}

Pharmacological treatment of AD with approved ChEIs and memantine lessen cognitive symptoms with no effect on disease progression; therefore, there is a need for promising DMTs to delay progression or 
Table 1

CSF biomarkers - sensitivity and specificity

\begin{tabular}{|c|c|c|c|c|c|c|}
\hline Studies & Sample size & Follow-up & Biomarker(s) & Cut-off definition & Sensitivity & Specificity \\
\hline Wallin et al. [74] & $\begin{array}{l}\mathrm{N}=50 \\
21 \text { probable AD patients } \\
24 \text { controls }\end{array}$ & 5- and 6-year & $\begin{array}{l}\downarrow \mathrm{CSF} A \beta_{42} \\
\uparrow \mathrm{CSF} \text {-Tau } \\
\uparrow \mathrm{CSF} \text { p-Tau }\end{array}$ & $\begin{array}{l}\text { Cut-off in healthy controls } \\
\text { CSF A } \beta_{42}:<427 \mathrm{ng} / 1 \\
\text { CSF t-Tau: }<445 \mathrm{ng} / 1 \\
\text { CSF p-Tau: }<74 \mathrm{ng} / 1\end{array}$ & $\begin{array}{l}\text { CSF A } \beta_{42}: 86 \%(18 / 21) \\
\text { CSF t-Tau: } 86 \%(18 / 21) \\
\text { CSF p-Tau: } 60 \%(12 / 20)\end{array}$ & $\begin{array}{l}\text { CSF A } \beta_{42}: 88 \%(21 / 24) \\
\text { CSF t-Tau: } 88 \%(21 / 24) \\
\text { CSF p-Tau: } 88 \%(21 / 24)\end{array}$ \\
\hline Hansson et al. [75] & $\begin{array}{l}180 \text { MCI patients } \\
137 \text { CSF was collected } \\
\text { (56 stable MCI } \\
57 \text { MCI-AD } \\
21 \text { MCI other } \\
3 \text { died before } 4 \text { years } \\
\text { follow-up) }\end{array}$ & 4.0-6.8 years & $\begin{array}{l}\downarrow \mathrm{CSFA} \beta_{42}-\mathrm{p}-\mathrm{Tau}_{181} \\
\downarrow \text { CSF A } \beta_{42} \\
\uparrow \mathrm{CSF} \text { t-Tau } \\
\uparrow \text { CSF p-Tau } 181\end{array}$ & $\begin{array}{l}\text { Cut-off for pathological CSF: } \\
\text { t-Tau: }>350 \mathrm{ng} / 1 \\
\mathrm{~A} \beta_{42}:<530 \mathrm{ng} / 1 \\
\text { p-Tau } 181:>60 \mathrm{ng} / 1 \\
\mathrm{~A} \beta_{42}-\text { p-Tau } \\
181:<6.5\end{array}$ & CSF $A \beta_{42}$ and t-Tau: $95 \%$ & CSF $A \beta_{42}$ and $t-T a u: ~ 83 \%$ \\
\hline Hansson et al. [78] & $\begin{array}{l}137 \text { MCI patients CSF } \\
\text { was collected }\end{array}$ & 4.0-6.8 years & $\begin{array}{l}\downarrow \mathrm{CSFA} \beta_{42} \\
\downarrow \mathrm{CSF} \mathrm{A} \beta_{42} / \mathrm{A} \beta_{40}\end{array}$ & $\begin{array}{l}\text { Cut-off values for pathological } \\
\text { CSF: } \\
\mathrm{A} \beta_{42}: \leq 0.64 \mathrm{ng} / \mathrm{ml} \\
\mathrm{A} \beta_{42}-\mathrm{A} \beta_{40}: \leq 0.95\end{array}$ & $\begin{array}{l}\mathrm{CSF} A \beta_{42}: 93 \% \text { (95\%CI 82-98) } \\
\mathrm{A} \beta_{42}-\mathrm{A} \beta_{40} \text { ratio: } 87 \%(95 \% \mathrm{CI} \\
\quad 76-95)\end{array}$ & $\begin{array}{l}\mathrm{CSF} A \beta_{42}: 53 \%(95 \% \mathrm{CI} 41-64) \\
\mathrm{CSF} A \beta_{42}-\mathrm{A} \beta_{40}: 78 \%(95 \% \mathrm{CI} \\
\quad 67-86)\end{array}$ \\
\hline Mattsson et al. [76] & $\begin{array}{l}750 \text { patients with MCI } \\
529 \text { with AD } \\
304 \text { controls }\end{array}$ & $2-11$ years & $\begin{array}{l}\text { Incipient } \mathrm{AD} \\
\downarrow \mathrm{CSF} \mathrm{A} \beta_{42}\end{array}$ & $\begin{array}{l}\text { Incipient } \mathrm{AD} \\
\mathrm{CSF} A \beta_{42}: \leq 482 \mathrm{ng} / \mathrm{l}\end{array}$ & $\begin{array}{l}\text { Incipient AD } \\
\text { CSF A } \beta_{42}: 79 \% \text { (215 of } 271 \text {; } \\
\text { 95\%CI 74-84) }\end{array}$ & $\begin{array}{l}\text { Incipient AD } \\
\text { CSF A } \beta_{42}: 65 \% \text { (321 of } 479 \text {; } \\
\text { 95\%CI, 61-69) }\end{array}$ \\
\hline & $\begin{array}{l}304 \text { controls } \\
420 \text { stable } \mathrm{MCI} \\
271 \text { incipient } \mathrm{AD}\end{array}$ & & $\begin{array}{l}\uparrow \text { CSF t-Tau } \\
\uparrow \text { CSF p-Tau }\end{array}$ & $\begin{array}{l}\text { CSF t-Tau: } \geq 320 \mathrm{ng} / 1 \\
\text { CSF p-Tau: } \geq 52 \mathrm{ng} / 1\end{array}$ & $\begin{array}{l}\text { CSF p-Tau: } 84 \% \text { ( } 227 \text { of } 270 \text {; } \\
\text { 95\%CI, 80-88) } \\
\text { CSF t-Tau: } 86 \%(232 \text { of } 271 \text {; } \\
\text { 95\%CI } 82-90)\end{array}$ & $\begin{array}{l}\text { CSF p-Tau: } 47 \% \text { (225 of } 479 \text {; } \\
\text { 95\% CI, 42-52) } \\
\text { CSF t-Tau: } 56 \%(268 \text { of } 479 \text {, } \\
\text { 95\%CI } 51-61)\end{array}$ \\
\hline Shea et al. [77] & $\begin{array}{l}\mathrm{N}=48 \\
24 \text { AD patients } \\
12 \text { non-demented control } \\
12 \text { Non-AD dementia }\end{array}$ & & $\begin{array}{l}\downarrow \mathrm{CSF} A \beta_{42} \\
\uparrow \mathrm{CSF} \text { tau } \\
\uparrow \mathrm{CSF} \text {-Tau } 181 \\
\downarrow \mathrm{A} \beta_{42}-\mathrm{t}-\mathrm{Tau} \\
\downarrow \mathrm{A} \beta_{42}-\mathrm{p}-\mathrm{Tau}\end{array}$ & $\begin{array}{l}\text { Tau: }>325.7 \mathrm{pg} / \mathrm{ml} \\
\text { p-Tau: }>44.25 \mathrm{pg} / \mathrm{ml} \\
\mathrm{A} \beta_{42}: \leq 357.1 \mathrm{pg} / \mathrm{ml} \\
\mathrm{A} \beta_{40}:>331.2 \mathrm{pg} / \mathrm{ml} \\
\mathrm{A} \beta_{42}-\mathrm{t}-\mathrm{Tau}: \leq 1.54 \\
\mathrm{~A} \beta_{42}-\mathrm{p}-\mathrm{Tau}: \leq 9.84\end{array}$ & $\begin{array}{l}\text { t-Tau: } 83 \% \\
\text { p-Tau: } 79 \% \\
\text { A } \beta_{42}: 75 \% \\
\text { A } \beta_{40}: 46 \% \\
A \beta_{42}-t-T a u: 96 \% \\
A \beta_{42}-\text { - }- \text { Tau: } 92 \%\end{array}$ & $\begin{array}{l}\text { CSF t-Tau: } 91 \% \\
\text { CSF p-Tau: } 92 \% \\
\text { CSF A } \beta_{42}: 83 \% \\
\text { A } \beta_{40}: 83 \% \\
\text { CSF A } \beta_{42}-\text { t-Tau: } 83 \% \\
\text { CSF } A \beta_{42}-\text { p-Tau: } 83 \%\end{array}$ \\
\hline Park et al. [79] & $\begin{array}{l}71 \text { controls } \\
76 \text { patients with } \mathrm{AD} \\
\text { dementia }\end{array}$ & & $\begin{array}{l}\downarrow \mathrm{CSFA} \beta_{42} \\
\uparrow \mathrm{CSF} \text { t-Tau }\end{array}$ & $\begin{array}{l}\text { AD dementia versus control } \\
\mathrm{A} \beta_{42}:<481 \mathrm{pg} / \mathrm{ml}\end{array}$ & $\begin{array}{l}\mathrm{AD} \text { dementia versus control } \\
\mathrm{A} \beta_{42}: 94 \%\end{array}$ & $\begin{array}{l}\text { AD dementia versus control } \\
A \beta_{42}: 87 \%\end{array}$ \\
\hline & $\begin{array}{l}47 \text { OND with cognitive } \\
\text { decline }\end{array}$ & & $\uparrow$ CSF p-Tau & $\begin{array}{l}\text { t-Tau: }>326 \mathrm{pg} / \mathrm{ml} \\
\text { p-Tau: }>57 \mathrm{pg} / \mathrm{ml} \\
\text { t-Tau/A } \beta_{42}:>0.55 \\
\text { p-Tau/A } \beta_{42}:>0.10 \\
\text { AD dementia versus OND } \\
\text { A } \beta_{42}: 478 \mathrm{pg} / \mathrm{ml} \\
\text { tTau: } 327 \mathrm{pg} / \mathrm{ml} \\
\text { p-Tau: } 48 \mathrm{pg} / \mathrm{ml} \\
\text { t-Tau/A } \beta_{42}: 0.76 \\
\text { p-Tau/A } \beta_{42}: 0.12\end{array}$ & $\begin{array}{l}\text { t-Tau: } 84 \% \\
\text { p-Tau: } 72 \% \\
\text { t-Tau/A } \beta_{42}: 99 \% \\
\text { p-Tau/A } \beta_{42}: 96 \% \\
\text { AD dementia versus OND } \\
\text { A } \beta_{42}: 93 \% \\
\text { t-Tau: } 83 \% \\
\text { p-Tau: } 86 \% \\
\text { tTau/A } \beta_{42}: 93 \% \\
\text { pTau/A } \beta_{42}: 95 \%\end{array}$ & $\begin{array}{l}\text { t-Tau: } 96 \% \\
\text { p-Tau: } 90 \% \\
\text { t-Tau/A } \beta_{42}: 95 \% \\
\text { p-Tau/A } \beta_{42}: 96 \% \\
\text { AD dementia versus OND } \\
\text { A } \beta_{42}: 70 \% \\
\text { t-Tau: } 85 \% \\
\text { p-Tau: } 85 \% \\
\text { tTau/A } \beta_{42}: 92 \% \\
\text { pTau/A } \beta_{42}: 89 \%\end{array}$ \\
\hline
\end{tabular}


prevent AD. There were a total of 112 agents in development for $\mathrm{AD}$ treatment in phase $\mathrm{I}(n=23$ agents in 25 trials), phase II ( $n=63$ agents in 75 trials), and phase III ( $n=26$ agents in 35 trials) stages [137]. Of these, the majority were DMTs (63\%), but only a few disease-modifying compounds are promising and undergoing phase III trials. More recently, Cummings and his colleagues [138] reviewed clinicaltrials.gov for AD clinical studies and provided an update on AD drug development pipeline. In the 2019 pipeline, there were a total of 132 agents in the AD clinical trials (31 phase I studies: 30 agents, 83 phase II studies: 74 agents, 42 phase III studies: 28 agents) than 112 agents observed in the 2018 pipeline [137]. Of the 132 agents, $96(73 \%)$ were intend for disease modification in $\mathrm{AD}$ clinical trials.

Aducanumab (BIIB037) is human monoclonal antibody that selectively binds to aggregated forms of $A \beta$ [139] and reduces $A \beta$ plaques in $\mathrm{AD}$ [140]. Results from the interim analysis of the PRIME study (ClinicalTrials.gov identifier NCT01677572 [141]) supported the development of aducanumab [140]. ENGAGE (ClinicalTrials.gov identifier NCT02477800 [142]; estimated to enroll 1605 patients) and EMERGE (ClinicalTrials.gov identifier NCT02484547 [143]; estimated to enroll 1605 patients) are two ongoing randomized, doubleblind phase III clinical studies to evaluate the effect of aducanumab compared with placebo (primary endpoint: Clinical Dementia Rating-Sum of Boxes [CDR-SB] score) in patients with early stages of AD. Recently, results based on new analysis of EMERGE a Phase III study [144] in patients with early AD exposed to high dose aducanumab showed a significant reduction of clinical decline in CDR-SB scores at 78 weeks from baseline (23\% versus placebo, $p=0.01)$. CAD106 is a second-generation active $\mathrm{A} \beta$ immunotherapy designed to induce antibody production against $A \beta_{1-6}$ peptide fragments, avoiding the A $\beta$-specific T-cell response [145]; whereas, CNP520 is an orally active $\beta$-secretase (BACE-1) inhibitor that reduces $A \beta$-peptide production [146]. The generation program is testing CNP520 and CAD106 in two pivotal studies of participants at risk for the onset of AD clinical symptoms (Generation Study 1 [estimated to enroll 1340 patients]: ClinicalTrials.gov identifier: NCT02565511 [147] [CNP520 and CAD106], and Generation Study 2 [estimated to enroll 2000 patients]: ClinicalTrials.gov Identifier: NCT03131453 [148] [CNP520]) using dual primary outcome measures including 1) time to diagnosis of MCI due to $\mathrm{AD}$ or dementia due to $\mathrm{AD}$ and 2) change in the Alzheimer's Prevention Initiative Composite Cognitive (APCC) Test Score. These outcome measures were developed as sensitive instruments to evaluate treatment effects and assess the cognitive decline in individuals at risk of progression of AD. Further, the investigation of the BACE1 inhibitor CNP520 was discontinued in two pivotal Phase II/III studies in the Alzheimer's Prevention Initiative Generation Program [149].

\section{CONCLUSIONS}

In the clinical practice, diagnosis of $\mathrm{AD}$ is mainly based on the observation of cognitive decline, and definitive $\mathrm{AD}$ is confirmed upon histological examination of the brain tissue. The advances in neuroimaging and the application of $\mathrm{AD}$ biomarkers helps in better understanding of early pathological changes in $\mathrm{AD}$ brain. This review paper identified $A \beta_{42}$ and tau are the core CSF biomarkers used as clinical diagnostic tools in $\mathrm{AD}$, and that the application of approved radiotracers (florbetapir, flutemetamol, or florbetaben) for amyloid-PET brain imaging serves as a robust tool to detect early stages of $\mathrm{AD}$.

The CSF $A \beta_{42}$ and tau are biomarkers reflecting brain pathology and the alterations in concentrations of these proteins indicate early and late stages of AD. Increasing evidence shows that the CSF biomarkers $\left(\mathrm{A} \beta_{42}\right.$ and tau) have a high sensitivity and specificity profile, and therefore have clinical utility in prediction of $\mathrm{AD}$ stages. Currently, the progression of $\mathrm{AD}$ cannot be stopped or reversed; however, the DMTs are promising and undergoing phase III trials for the early stages of AD. Contemporary AD management should advocate in identifying biomarkers for pre-dementia diagnosis and recommend DMTs to possibly reverse the pathology.

\section{ACKNOWLEDGMENTS}

This review article is sponsored by Novartis (Singapore) Pte. Ltd. The publication processing fees were funded by Novartis (Singapore) Pte. Ltd. The authors thank Stephen Christopher for reviewing this manuscript and providing helpful suggestions.

All authors of this review article met the International Committee of Medical Journal Editors (ICMJE) criteria for authorship and approved the final version to be published. 


\section{CONFLICT OF INTEREST}

Oliver Simon and Ananda Krishna Karanam are employees of Novartis. The remaining authors have nothing to disclose.

\section{REFERENCES}

[1] Gale SA, Acar D, Daffner KR (2018) Dementia. Am J Med 131, 1161-1169.

[2] Scott KR, Barrett AM (2007) Dementia syndromes: Evaluation and treatment. Expert Rev Neurother 7, 407-422.

[3] Prizer LP, Zimmerman S (2018) Progressive support for activities of daily living for persons living with dementia. Gerontologist 58, S74-87.

[4] Jing W, Willis R, Feng Z (2016) Factors influencing quality of life of elderly people with dementia and care implications: A systematic review. Arch Gerontol Geriatr 66, 23-41.

[5] Prince M, Wimo A, Guerchet M, Ali G-C, Wu Y-T, Prina M (2015) World Alzheimer Report 2015. The global impact of dementia: An analysis of prevalence, incidence, cost and trends. Alzheimer's Disease International, London. http:// www.alz.co.uk/research/WorldAlzheimerReport2015.pdf. Accessed January 8, 2020.

[6] Zabalegui A, Hamers JP, Karlsson S, Leino-Kilpi H, Renom-Guiteras A, Saks K, Soto M, Sutcliffe C, Cabrera E (2014) Best practices interventions to improve quality of care of people with dementia living at home. Patient Educ Couns 95, 175-184

[7] Overshott R, Burns A (2005) Treatment of dementia. $J$ Neurol Neurosurg Psychiatry 76, v53-59.

[8] Magalingam KB, Radhakrishnan A, Ping NS, Haleagrahara N (2018) Current concepts of neurodegenerative mechanisms in Alzheimer's disease. Biomed Res Int 2018 , 3740461.

[9] Alzheimer's Association (2017) 2017 Alzheimer's disease facts and figures. Alzheimers Dement 17, 325-373.

[10] Kawas C, Gray S, Brookmeyer R, Fozard J, Zonderman A (2000) Age-specific incidence rates of Alzheimer's disease: The Baltimore longitudinal study of aging. Neurology 54, 2072-2077.

[11] Kanekar S, Poot JD (2014) Neuroimaging of vascular dementia. Radiol Clin North Am 52, 383-401.

[12] O'Brien JT, Thomas A (2015) Vascular dementia. Lancet 386, 1698-1706.

[13] Hanagasi HA, Tufekcioglu Z, Emre M (2017) Dementia in Parkinson's disease. J Neurol Sci 374, 26-31.

[14] Silbert LC, Kaye J (2010) Neuroimaging and cognition in Parkinson's disease dementia. Brain Pathol 20, 646-653.

[15] Hanson JC, Lippa CF (2009) Lewy body dementia. Int Rev Neurobiol 84, 215-228.

[16] Yousaf T, Dervenoulas G, Valkimadi PE, Politis M (2019) Neuroimaging in Lewy body dementia. JNeurol 266, 1-26.

[17] Gordon E, Rohrer JD, Fox NC (2016) Advances in neuroimaging in frontotemporal dementia. J Neurochem $\mathbf{1 3 8}$, 193-210.

[18] Olney NT, Spina S, Miller BL (2017) Frontotemporal dementia. Neurol Clin 35, 339-374.

[19] Aisen PS, Cummings J, Jack CR Jr, Morris JC, Sperling R, Frölich L, Jones RW, Dowsett SA, Matthews BR, Raskin J, Scheltens P, Dubois B (2017) On the path to 2025: Under- standing the Alzheimer's disease continuum. Alzheimers Res Ther 9,60 .

[20] Wilson RS, Segawa E, Boyle PA, Anagnos SE, Hizel LP, Bennett DA (2012) The natural history of cognitive decline in Alzheimer's disease. Psychol Aging 27, 1008-1017.

[21] Kamiya M, Osawa A, Kondo I, Sakurai T (2018) Factors associated with cognitive function that cause a decline in the level of activities of daily living in Alzheimer's disease. Geriatr Gerontol Int 18, 50-56.

[22] Bancher C, Lassmann H, Breitschopf H, Jellinger KA (1997) Mechanisms of cell death in Alzheimer's disease. J Neural Transm 50, 141-152.

[23] Donev R, Kolev M, Millet B, Thome, J (2009) Neuronal death in Alzheimer's disease and therapeutic opportunities. J Cell Mol Med 13, 4329-4348.

[24] Terry RD, Masliah E, Salmon DP, Butters N, DeTeresa R, Hill R, Hansen LA, Katzman R (1991) Physical basis of cognitive alterations in Alzheimer's disease: Synapse loss is the major correlate of cognitive impairment. Ann Neurol 30, 572-580.

[25] Riedel BC, Thompson PM, Brinton RD (2016) Age, APOE and sex: Triad of risk of Alzheimer's disease. $J$ Steroid Biochem Mol Biol 160, 134-147.

[26] Liu CC, Liu CC, Kanekiyo T, Xu H, Bu G (2013) Apolipoprotein E and Alzheimer disease: Risk, mechanisms and therapy. Nat Rev Neurol 9, 106-118.

[27] He W, Goodkind D, Kowal P. An aging world: 2015, international population reports. www.census.gov/content/ dam/Census/library/publications/2016/demo/p95-16-1. pdf. Accessed January 8, 2020.

[28] Haberstroh J, Hampel H, Pantel J (2010) Optimal management of Alzheimer's disease patients: Clinical guidelines and family advice. Neuropsychiatr Dis Treat 6, 243-253.

[29] Barage SH, Sonawane KD (2015) Amyloid cascade hypothesis: Pathogenesis and therapeutic strategies in Alzheimer's disease. Neuropeptides 52, 1-18.

[30] Adalbert R, Gilley J, Coleman MP (2007) A $\beta$, tau and ApoE4 in Alzheimer's disease: The axonal connection. Trends Mol Med 13, 135-142.

[31] Hardy J, Selkoe DJ (2002) The amyloid hypothesis of Alzheimer's disease: Progress and problems on the road to therapeutics. Science 297, 353-356.

[32] Serrano-Pozo A, Frosch MP, Masliah E, Hyman, BT (2011) Neuropathological alterations in Alzheimer disease. Cold Spring Harb Perspect Med 1, 1-23.

[33] Haass C, Kaether C, Thinakaran G, Sisodia S (2012) Trafficking and proteolytic processing of APP. Cold Spring Harb Perspect Med 2, 1-25.

[34] Chow VW, Mattson MP, Wong PC, Gleichmann M (2010) An overview of APP processing enzymes and products. Neuromolecular Med 12, 1-12.

[35] O'Brien RJ, Wong PC (2011) Amyloid precursor protein processing and Alzheimer's disease. Annu Rev Neurosci 34, 185-204.

[36] Storey E, Cappai R (1999) The amyloid precursor protein of Alzheimer's disease and the A $\beta$ peptide. Neuropathol Appl Neurobiol 25, 81-97.

[37] Hayden EY, Teplow DB (2013) Amyloid $\beta$-protein oligomers and Alzheimer's disease. Alzheimers Res Ther 5, 60 .

[38] Sengupta U, Nilson AN, Kayed R (2016) The role of amyloid- $\beta$ oligomers in toxicity, propagation, and immunotherapy. EBioMedicine 6, 42-49.

[39] Wang JZ, Xia YY, Grundke-Iqbal I, Iqbal K (2013) Abnormal hyperphosphorylation of tau: Sites, regulation, 
and molecular mechanism of neurofibrillary degeneration. J Alzheimers Dis 33, S123-139.

[40] Eckert A, Schmitt K, Gotz J (2011) Mitochondrial dysfunction - the beginning of the end in Alzheimer's disease? Separate and synergistic modes of tau and amyloid- $\beta$ toxicity. Alzheimers Res Ther 3, 15.

[41] Reddy PH (2011) Abnormal tau, mitochondrial dysfunction, impaired axonal transport of mitochondria, and synaptic deprivation in Alzheimer's disease. Brain Res 1415, 136-148.

[42] Swerdlow RH, Khan SM (2004) A "mitochondrial cascade hypothesis" for sporadic Alzheimer's disease. Med Hypotheses 63, 8-20.

[43] Swerdlow RH, Khan SM (2009) The Alzheimer's disease mitochondrial cascade hypothesis: An update. Exp Neurol 218, 308-315.

[44] Swerdlow RH, Burns, JM, Khan, SM (2010) The Alzheimer's disease mitochondrial cascade hypothesis. J Alzheimers Dis 20, S265-279.

[45] Ferencz B, Karlsson S, Kalpouzos G (2012) Promising genetic biomarkers of preclinical Alzheimer's disease: The influence of APOE and TOMM40 on brain integrity [Article ID 421452]. Int J Alzheimers Dis 2012, 421-452.

[46] Bronzuoli MR, Iacomino A, Steardo L, Scuderi C (2016) Targeting neuroinflammation in Alzheimer's disease. J Inflamm Res 9, 199-208.

[47] Heneka MT, Carson MJ, El Khoury J, Landreth GE, Brosseron F, Feinstein DL, Jacobs AH, Wyss-Coray T, Vitorica J, Ransohoff RM, Herrup K, Frautschy SA, Finsen B, Brown GC, Verkhratsky A, Yamanaka K, Koistinaho J, Latz E, Halle A, Petzold GC, Town T, Morgan D, Shinohara ML, Perry VH, Holmes C, Bazan NG, Brooks DJ, Hunot S, Joseph B, Deigendesch N, Garaschuk O, Boddeke E, Dinarello CA, Breitner JC, Cole GM, Golenbock DT, Kummer MP (2015) Neuroinflammation in Alzheimer's disease. Lancet Neurol 14, 388-405.

[48] McKhann G, Drachman D, Folstein M, Katzman R, Price D, Stadlan EM (1984) Clinical diagnosis of Alzheimer's disease: Report of the NINCDS-ADRDA work group under the auspices of department of health and human services task force on Alzheimer's Disease. Neurology 34, 939-944.

[49] American Psychiatric Association (2013) Diagnostic and Statistical Manual of Mental Disorders. American Psychiatric Association, Washington DC.

[50] Sachdev PS, Blacker D, Blazer DG, Ganguli M, Jeste DV, Paulsen JS, Petersen RC (2014) Classifying neurocognitive disorders: The DSM-5 approach. Nat Rev Neurol 10, 634-642.

[51] Dubois B, Feldman HH, Jacova C, Dekosky ST, Barberger-Gateau P, Cummings J, Delacourte A, Galasko D, Gauthier S, Jicha G, Meguro K, O’brien J, Pasquier F, Robert P, Rossor M, Salloway S, Stern Y, Visser PJ, Scheltens P (2007) Research criteria for the diagnosis of Alzheimer's disease: Revising the NINCDS-ADRDA criteria. Lancet Neurol 6, 734-746.

[52] Dubois B, Feldman HH, Jacova C, Cummings JL, Dekosky ST, Barberger-Gateau P, Delacourte A, Frisoni G, Fox NC, Galasko D, Gauthier S, Hampel H, Jicha GA, Meguro K, O'Brien J, Pasquier F, Robert P, Rossor M, Salloway S, Sarazin M, de Souza LC, Stern Y, Visser PJ, Scheltens P (2010) Revising the definition of Alzheimer's disease: A new lexicon. Lancet Neurol 9, 1118-1127.

[53] Dubois B, Feldman HH, Jacova C, Hampel H, Molinuevo JL, Blennow K, DeKosky ST, Gauthier S, Selkoe D, Bate- man R, Cappa S, Crutch S, Engelborghs S, Frisoni GB, Fox NC, Galasko D, Habert MO, Jicha GA, Nordberg A, Pasquier F, Rabinovici G, Robert P, Rowe C, Salloway S, Sarazin M, Epelbaum S, de Souza LC, Vellas B, Visser PJ, Schneider L, Stern Y, Scheltens P, Cummings JL (2014) Advancing research diagnostic criteria for Alzheimer's disease: The IWG-2 criteria. Lancet Neurol 13, 614-629.

[54] Dubois B, Hampel H, Feldman HH, Scheltens P, Aisen P, Andrieu S, Bakardjian H, Benali H, Bertram L, Blennow K, Broich K, Cavedo E, Crutch S, Dartigues JF, Duyckaerts C, Epelbaum S, Frisoni GB, Gauthier S, Genthon R, Gouw AA, Habert MO, Holtzman DM, Kivipelto M, Lista S, Molinuevo JL, O’Bryant SE, Rabinovici GD, Rowe C, Salloway S, Schneider LS, Sperling R, Teichmann M, Carrillo MC, Cummings J, Jack CR Jr (2016) Proceedings of the meeting of the international working (IWG) and the American Alzheimer's Association on "The Preclinical State of AD, July 23, 2015; Washington DC, USA. Preclinical Alzheimer's disease: Definition, natural history, and diagnostic criteria. Alzheimers Dement 12, 292-323.

[55] Jack CR, Jr, Albert MS, Knopman DS, McKhann GM, Sperling RA, Carrillo MC, Thies B, Phelps CH (2011) Introduction to the recommendations from the national institute on aging-Alzheimer's association workgroups on diagnostic guidelines for Alzheimer's disease. Alzheimers Dement 7, 257-262.

[56] Jack CR Jr, Bennett DA, Blennow K, Carrillo MC, Dunn B, Haeberlein SB, Holtzman DM, Jagust W, Jessen F, Karlawish J, Liu E, Molinuevo JL, Montine T, Phelps C, Rankin KP, Rowe CC, Scheltens P, Siemers E, Snyder HM, Sperling R; Contributors (2018) NIA-AA Research Framework: Toward a biological definition of Alzheimer's disease. Alzheimers Dement 14, 535-562.

[57] McKhann GM, Knopman DS, Chertkow H, Hyman BT, Jack CR Jr, Kawas CH, Klunk WE, Koroshetz WJ, Manly JJ, Mayeux R, Mohs RC, Morris JC, Rossor MN, Scheltens P, Carrillo MC, Thies B, Weintraub S, Phelps $\mathrm{CH}$ (2011) The diagnosis of dementia due to Alzheimer's disease: Recommendations from the National Institute on Aging-Alzheimer's Association workgroups on diagnostic guidelines for Alzheimer's disease. Alzheimers Dement 7, 263-269.

[58] Albert MS, DeKosky ST, Dickson D, Dubois B, Feldman HH, Fox NC, Gamst A, Holtzman DM, Jagust WJ, Petersen RC, Snyder PJ, Carrillo MC, Thies B, Phelps CH (2011) The diagnosis of mild cognitive impairment due to Alzheimer's disease: Recommendations from the National Institute on Aging-Alzheimer's Association workgroups on diagnostic guidelines for Alzheimer's disease. Alzheimers Dement 7, 270-279.

[59] Sperling RA, Aisen PS, Beckett LA, Bennett DA, Craft S, Fagan AM, Iwatsubo T, Jack CR Jr, Kaye J, Montine TJ, Park DC, Reiman EM, Rowe CC, Siemers E, Stern Y, Yaffe K, Carrillo MC, Thies B, Morrison-Bogorad M, Wagster MV, Phelps CH (2011) Toward defining the preclinical stages of Alzheimer's disease: Recommendations from the National Institute on Aging-Alzheimer's Association workgroups on diagnostic guidelines for Alzheimer's disease. Alzheimers Dement 7, 280-292.

[60] Visser PJ, Vos S, van Rossum I, Scheltens P (2012) Comparison of International Working Group criteria and National Institute on Aging-Alzheimer's Association criteria for Alzheimer's disease. Alzheimers Dement 8, 560-563. 
[61] Jack CR Jr, Bennett DA, Blennow K, Carrillo MC, Feldman HH, Frisoni GB, Hampel H, Jagust WJ, Johnson KA, Knopman DS, Petersen RC, Scheltens P, Sperling RA, Dubois B (2016) A/T/N: An unbiased descriptive classification scheme for Alzheimer disease biomarkers. Neurology 87, 539-547.

[62] Verghese PB, Castellano JM, Holtzman DM (2011) Apolipoprotein E in Alzheimer's disease and other neurological disorders. Lancet Neurol 10, 241-252.

[63] Farrer LA, Cupples LA, Haines JL, Hyman B, Kukull WA, Mayeux R, Myers RH, Pericak-Vance MA, Risch N, van Duijn CM (1997) Effects of age, sex, and ethnicity on the association between apolipoprotein E genotype and Alzheimer disease. A meta-analysis. APOE and Alzheimer disease meta analysis consortium. JAMA 278, 1349-1356.

[64] Ward A, Crean S, Mercaldi CJ, Collins JM, Boyd D, Cook MN, Arrighi HM (2012) Prevalence of apolipoprotein E4 genotype and homozygotes (APOE e4/4) among patients diagnosed with Alzheimer's disease: A systematic review and meta-analysis. Neuroepidemiology 38, 1-17.

[65] Liu M, Bian C, Zhang J, Wen F (2014) Apolipoprotein E gene polymorphism and Alzheimer's disease in Chinese population: A meta-analysis. Sci Rep 4, 4383.

[66] Mielke MM, Vemuri P, Rocca WA (2014) Clinical epidemiology of Alzheimer's disease: Assessing sex and gender differences. Clin Epidemiol 6, 37-48.

[67] Neu SC, Pa J, Kukull W, Beekly D, Kuzma A, Gangadharan P, Wang LS, Romero K, Arneric SP, Redolfi A, Orlandi D, Frisoni GB, Au R, Devine S, Auerbach S, Espinosa A, Boada M, Ruiz A, Johnson SC, Koscik R, Wang JJ, Hsu WC, Chen YL, Toga AW (2017) Apolipoprotein E genotype and sex risk factors for Alzheimer disease: A meta-analysis. JAMA Neurol 74, 1178-1189.

[68] Vemuri P, Wiste HJ, Weigand SD, Knopman DS, Shaw LM, Trojanowski JQ, Aisen PS, Weiner M, Petersen RC, Jack CR Jr; Alzheimer's Disease Neuroimaging Initiative (2010) Effect of apolipoprotein E on biomarkers of amyloid load and neuronal pathology in Alzheimer disease Ann Neurol 67, 308-316.

[69] Lautner R, Insel PS, Skillback T, Olsson B, Landén M, Frisoni GB, Herukka SK, Hampel H, Wallin A, Minthon L, Hansson O, Blennow K, Mattsson N, Zetterberg H (2017) Preclinical effects of APOE $\varepsilon 4$ on cerebrospinal fluid A 342 concentrations. Alzheimers Res Ther $\mathbf{9}, 87$.

[70] Marioni RE, Campbell A, Scotland G, Hayward C, Porteous DJ, Deary IJ (2016) Differential effects of the APOE e4 allele on different domains of cognitive ability across the life-course. Eur J Hum Genet 24, 919-923.

[71] Mayeux R (2004) Biomarkers: Potential uses and limitations. NeuroRx 1, 182-188.

[72] Blennow K (2005) CSF biomarkers for Alzheimer's disease: Use in early diagnosis and evaluation of drug treatment. Expert Rev Mol Diagn 5, 661-672.

[73] Csernansky JG, Miller JP, McKeel D, Morris JC (2002) Relationships among cerebrospinal fluid biomarkers in dementia of the Alzheimer type. Alzheimer Dis Assoc Disord 16, 144-149.

[74] Wallin AK, Blennow K, Andreasen N, Minthon L (2006) CSF biomarkers for Alzheimer's disease: Levels of $\beta$-amyloid, tau, phosphorylated tau relate to clinical symptoms and survival. Dement Geriatr Cogn Disord 21, 131-138.

[75] Hansson O, Zetterberg H, Buchhave P, Londos E, Blennow K, Minthon L (2006) Association between CSF biomark- ers and incipient Alzheimer's disease in patients with mild cognitive impairment: A follow-up study. Lancet Neurol 5, 228-234.

[76] Mattsson N, Zetterberg H, Hansson O, Andreasen N, Parnetti L, Jonsson M, Herukka SK, van der Flier WM, Blankenstein MA, Ewers M, Rich K, Kaiser E, Verbeek M, Tsolaki M, Mulugeta E, Rosén E, Aarsland D, Visser PJ, Schröder J, Marcusson J, de Leon M, Hampel H, Scheltens P, Pirttilä T, Wallin A, Jönhagen ME, Minthon L, Winblad B, Blennow K (2009) CSF biomarkers and incipient Alzheimer disease in patients with mild cognitive impairment. JAMA 302, 385-393.

[77] Shea YF, Chu LW, Zhou L, Li WM, Lin OY, Chan MN, Xu A, Wong R, Ho TY, Liu KW, Ha J, Daniel TW, Song YQ, Lam KS (2013) Cerebrospinal fluid biomarkers of Alzheimer's disease in Chinese patients: A pilot study. Am J Alzheimers Dis Other Demen 28, 769-775.

[78] Hansson O, Zetterberg H, Buchhave P, Andreasson U, Londos E, Minthon L, Blennow K (2007) Prediction of Alzheimer's disease using the CSF $A \beta 42 / A \beta 40$ ratio in patients with mild cognitive impairment. Dement Geriatr Cogn Disord 23, 316-320.

[79] Park SA, Chae WS, Kim HJ, Shin HS, Kim S, Im JY, Ahn SI, Min KD, Yim SJ, Ye BS, Seo SW, Jeong JH, Park KW, Choi SH, Na DL (2017) Cerebrospinal fluid biomarkers for the diagnosis of Alzheimer disease in South Korea. Alzheimer Dis Assoc Disord 31, 13-18.

[80] Lafirdeen ASM, Cognat E, Sabia S, Hourregue C, Lilamand M, Dugravot A, Bouaziz-Amar E, Laplanche JL, Hugon J, Singh-Manoux A, Paquet C, Dumurgier J (2019) Biomarker profiles of Alzheimer's disease and dynamic of the association between cerebrospinal fluid levels of $\beta$-amyloid peptide and tau. PLoS One 14, 1-13.

[81] Olsson B, Lautner R, Andreasson U, Öhrfelt A, Portelius E, Bjerke M, Hölttä M, Rosén C, Olsson C, Strobel G, Wu E, Dakin K, Petzold M, Blennow K, Zetterberg $\mathrm{H}$ (2016) CSF and blood biomarkers for the diagnosis of Alzheimer's disease: A systematic review and metaanalysis. Lancet Neurol 15, 673-684.

[82] Alzforum Alzbiomarker Version $2.0 \quad$ (2017) http://www.alzforum.org/alzbiomarker. Accessed January 8, 2020.

[83] Gurjeet Kaur Virk, Anne Poljak, Nady Braidy, Perminder S. Sachdev (2018) CSF and blood biomarkers of earlyonset Alzheimer's disease: A systematic review and metaanalysis [poster p3-226] Alzheimers Dement 14, P1158.

[84] Hansson O, Zetterberg H, Vanmechelen E, Scheltens P, Blankenstein MA (2010) Evaluation of plasma $A \beta 40$ and $\mathrm{A} \beta 42$ as predictors of conversion to Alzheimer's disease in patients with mild cognitive impairment. Neurobiol Aging 31, 357-367.

[85] Lövheim H, Elgh F, Johansson A, Zetterberg H, Blennow K, Hallmans G, Eriksson S (2017) Plasma concentrations of free amyloid $\beta$ cannot predict the development of Alzheimer's disease. Alzheimers Dement 13, 778-782.

[86] Mattsson N, Zetterberg H, Janelidze S, Insel PS, Andreasson U, Stomrud E, Palmqvist S, Baker D, Tan Hehir CA, Jeromin A, Hanlon D, Song L, Shaw LM, Trojanowski JQ, Weiner MW, Hansson O, Blennow K; ADNI Investigators (2016) Plasma tau in Alzheimer disease. Neurology 87, 1827-1835.

[87] Nakamura A, Kaneko N, Villemagne VL, Kato T, Doecke J, Doré V, Fowler C, Li QX, Martins R, Rowe C, Tomita T, Matsuzaki K, Ishii K, Ishii K, Arahata Y, Iwamoto S, Ito K, Tanaka K, Masters CL, Yanagisawa K (2018) High per- 
formance plasma amyloid- $\beta$ biomarkers for Alzheimer's disease. Nature 554, 249-254.

[88] Mattsson N, Andreasson U, Zetterberg H, Blennow K; Alzheimer's Disease Neuroimaging Initiative (2017) Association of plasma neurofilament light with neurodegeneration in patients with Alzheimer disease. JAMA Neurol 74, 557-566.

[89] Zhou W, Zhang J, Ye F, Xu G, Su H, Su Y, Zhang X; Alzheimer's Disease Neuroimaging Initiative (2017) Plasma neurofilament light chain levels in Alzheimer's disease. Neurosci Lett 650, 60-64.

[90] Neergaard JS, Dragsbæk K, Christiansen C, Karsdal MA, Brix S, Henriksen K (2018) Two novel blood-based biomarker candidates measuring degradation of tau are associated with dementia: A prospective study. PLoS One 13, 1-13.

[91] Nabers A, Perna L, Lange J, Mons U, Schartner J, Güldenhaupt J, Saum KU, Janelidze S, Holleczek B, Rujescu D, Hansson O, Gerwert K, Brenner H (2018) Amyloid blood biomarker detects Alzheimer's disease. EMBO Mol Med 10 1-11.

[92] Mielke MM, Hagen CE, Xu J, Chai X, Vemuri P, Lowe VJ, Airey DC, Knopman DS, Roberts RO, Machulda MM, Jack CR Jr, Petersen RC, Dage JL (2018) Plasma phosphotau181 increases with Alzheimer's disease clinical severity and is associated with tau- and amyloid-positron emission tomography. Alzheimers Dement 14, 989-997.

[93] Shahpasand-Kroner H, Klafki HW, Bauer C, Schuchhardt J, Hüttenrauch M, Stazi M, Bouter C, Wirths O, Vogelgsang J, Wiltfang J (2018) A two-step immunoassay for the simultaneous assessment of $A \beta 38, A \beta 40$ and $A \beta 42$ in human blood plasma supports the $A \beta 42 / A \beta 40$ ratio as a promising biomarker candidate of Alzheimer's disease. Alzheimers Res Ther 10, 121.

[94] Park JC, Han SH, Yi D, Byun MS, Lee JH, Jang S, Ko K, Jeon SY, Lee YS, Kim YK, Lee DY, Mook-Jung I (2019) Plasma tau/amyloid- $\beta 1-42$ ratio predicts brain tau deposition and neurodegeneration in Alzheimer's disease. Brain 142, 771-786.

[95] Schindler SE, Bollinger JG, Ovod V, Mawuenyega KG, Li Y, Gordon BA, Holtzman DM, Morris JC, Benzinger TLS, Xiong C, Fagan AM, Bateman RJ (2019) High-precision plasma $\beta$-amyloid $42 / 40$ predicts current and future brain amyloidosis. Neurology 93, e1647-e1659.

[96] Palmqvist S, Janelidze S, Stomrud E, Zetterberg H, Karl J, Zink K, Bittner T, Mattsson N, Eichenlaub U, Blennow K, Hansson O (2019) Performance of fully automated plasma assays as screening tests for Alzheimer disease-related $\beta$ Amyloid status. JAMA Neurol 76, 1060-1069.

[97] Florbetapir F 18 Injection (Amyvid ${ }^{\mathrm{TM}}$ ). http://www. accessdata.fda.gov/drugsatfda_docs/label/2012/202008s0 00lbl.pdf. Accessed January 8, 2020.

[98] Flutemetamol F 18 Injection (Vizamyl $^{\mathrm{TM}}$ ). http://www. accessdata.fda.gov/drugsatfda_docs/label/2017/203137s0 08lbl.pdf. Accessed January 8, 2020.

[99] Florbetaben F 18 Injection (NeuraCeq ${ }^{\mathrm{TM}}$ ). http://www. accessdata.fda.gov/drugsatfda_docs/label/2014/204677s0 00lbl.pdf. Accessed January 8, 2020.

[100] Clark CM, Schneider JA, Bedell BJ, Beach TG, Bilker WB, Mintun MA, Pontecorvo MJ, Hefti F, Carpenter AP, Flitter ML, Krautkramer MJ, Kung HF, Coleman RE, Doraiswamy PM, Fleisher AS, Sabbagh MN, Sadowsky CH, Reiman EP, Zehntner SP, Skovronsky DM; AV45-A07 study group (2011) Use of Florbetapir-PET for imaging $\beta$-amyloid pathology. JAMA 305, 275-283.
[101] Clark CM, Pontecorvo MJ, Beach TG, Bedell BJ, Coleman RE, Doraiswamy PM, Fleisher AS, Reiman EM, Sabbagh MN, Sadowsky CH, Schneider JA, Arora A, Carpenter AP, Flitter ML, Joshi AD, Krautkramer MJ, Lu M, Mintun MA, Skovronsky DM; AV-45-A16 Study Group (2012) Cerebral PET with florbetapir compared with neuropathology at autopsy for detection of neuritic amyloid- $\beta$ plaques: A prospective cohort study. Lancet Neurol 11, 669-678.

[102] Curtis C, Gamez JE, Singh U, Sadowsky CH, Villena T, Sabbagh MN, Beach TG, Duara R, Fleisher AS, Frey KA, Walker Z, Hunjan A, Holmes C, Escovar YM, Vera CX, Agronin ME, Ross J, Bozoki A, Akinola M, Shi J, Vandenberghe R, Ikonomovic MD, Sherwin PF, Grachev ID, Farrar G, Smith AP, Buckley CJ, McLain R, Salloway S (2015) Phase 3 trial of flutemetamol labeled with radioactive fluorine 18 imaging and neuritic plaque density. JAMA Neurol 72, 287-294.

[103] Sabri O, Sabbagh MN, Seibyl J, Barthel H, Akatsu H, Ouchi Y, Senda K, Murayama S, Ishii K, Takao M, Beach TG, Rowe CC, Leverenz JB, Ghetti B, Ironside JW, Catafau AM, Stephens AW, Mueller A, Koglin N, Hoffmann A, Roth K, Reininger C, Schulz-Schaeffer WJ; Florbetaben Phase 3 Study Group (2015) Florbetaben PET imaging to detect amyloid beta plaques in Alzheimer's disease: Phase 3 study. Alzheimers Dement 11, 964-974.

[104] Brier MR, Gordon B, Friedrichsen K, McCarthy J, Stern A, Christensen J, Owen C, Aldea P, Su Y, Hassenstab J, Cairns NJ, Holtzman DM, Fagan AM, Morris JC, Benzinger TL, Ances BM (2016) Tau and A $\beta$ imaging, CSF measures, and cognition in Alzheimer's disease. Sci Transl Med 8, $1-10$.

[105] Ossenkoppele R, Smith R, Ohlsson T, Strandberg O, Mattsson N, Insel PS, Palmqvist S, Hansson O (2019) Associations between tau, $\mathrm{A} \beta$, and cortical thickness with cognition in Alzheimer disease. Neurology 92, e601-e612.

[106] Avila J (2010) Intracellular and extracellular tau. Front Neurosci 4, 1-10.

[107] Pike VW (2009) PET radiotracers: Crossing the bloodbrain barrier and surviving metabolism. Trends Pharmacol Sci 30, 431-440.

[108] Martin L, Latypova X, Terro F (2011) Post-translational modifications of tau protein: Implications for Alzheimer's disease. Neurochem Int 58, 458-471.

[109] Buée L, Bussière T, Buée-Scherrer V, Delacourte A, Hof PR (2000) Tau protein isoforms, phosphorylation and role in neurodegenerative disorders. Brain Res Brain Res Rev 33, 95-130.

[110] Villemagne VL, Fodero-Tavoletti MT, Masters CL, Rowe CC (2015) Tau imaging: Early progress and future directions. Lancet Neurol 14, 114-124.

[111] Ossenkoppele R, Rabinovici GD, Smith R, Cho H, Schöll M, Strandberg O, Palmqvist S, Mattsson N, Janelidze S, Santillo A, Ohlsson T, Jögi J, Tsai R, La Joie R, Kramer J, Boxer AL, Gorno-Tempini ML, Miller BL, Choi JY, Ryu YH, Lyoo CH, Hansson O (2018) Discriminative accuracy of $[18 \mathrm{~F}]$ flortaucipir positron emission tomography for Alzheimer disease vs other neurodegenerative disorders. JAMA 320, 1151-1162.

[112] Smith R, Wibom M, Pawlik D, Englund E, Hansson O (2019) Correlation of in vivo [18F] flortaucipir with postmortem Alzheimer disease tau pathology. JAMA Neurol 76, 310-317.

[113] U.S. National library of medicine. 18F-AV-1451 autopsy study. https://clinicaltrials.gov/ct2/show/NCT02516046. Accessed January 8, 2020. 
[114] PR Newswire. http://www.prnewswire.com/news-releases/lilly-announces-positive-phase-3-results-in-studyof-flortaucipir-pet-imaging-agent-300707314.html. Accessed January 8, 2020.

[115] Hampel H, Mesulam MM, Cuello AC, Farlow MR, Giacobini E, Grossberg GT, Khachaturian AS, Vergallo A, Cavedo E, Snyder PJ, Khachaturian ZS (2018) The cholinergic system in the pathophysiology and treatment of Alzheimer's disease. Brain 141, 1917-1933.

[116] Deardorff WJ, Feen E, Grossberg GT (2015) The use of cholinesterase inhibitors across all stages of Alzheimer's disease. Drug Aging 32, 537-547.

[117] Olivares D, Deshpande VK, Shi Y, Lahiri DK, Greig NH, Rogers JT, Huang X (2012) N-methyl D-aspartate (NMDA) receptor antagonists and memantine treatment for Alzheimer's disease, vascular dementia and Parkinson's disease. Curr Alzheimer Res 9, 746-758.

[118] Kandiah N, Pai MC, Senanarong V, Looi I, Ampil E, Park KW, Karanam AK, Christopher S (2017) Rivastigmine: The advantages of dual inhibition of acetylcholinesterase and butyrylcholinesterase and its role in subcortical vascular dementia and Parkinson's disease dementia. Clin Interv Aging 12, 697-707.

[119] Donepezil (Aricept ${ }^{\circledR}$ ). http://www.aricept.com/docs/ pdf/aricept_PI.pdf. Accessed January 8, 2020.

[120] Rogers SL, Doody RS, Mohs RC, Friedhoff LT (1998) Donepezil improves cognition and global function in Alzheimer disease: A 15-week, double-blind, placebocontrolled study. Donepezil Study Group. Arch Intern Med 158, 1021-1031.

[121] Winblad B, Kilander L, Eriksson S, Minthon L, Båtsman S, Wetterholm AL, Jansson-Blixt C, Haglund A; Severe Alzheimer's Disease Study Group (2006) Donepezil in patients with severe Alzheimer's disease: Double-blind, parallel-group, placebo-controlled study. Lancet 367, 1057-1065.

[122] Homma A, Imai Y, Tago H, Asada T, Shigeta M, Iwamoto T, Takita M, Arimoto I, Koma H, Ohbayashi T (2008) Donepezil treatment of patients with severe Alzheimer's disease in a Japanese population: Results from a 24week, double-blind, placebo-controlled, randomized trial. Dement Geriatr Cogn Disord 25, 399-407.

[123] Galantamine (Razadyne $\mathrm{ER}^{\circledR}$ and Razadyne ${ }^{\circledR}$ ). http:// www.janssenmd.com/pdf/razadyne/razadyne_pi.pdf. Accessed January 8, 2020.

[124] Raskind MA, Peskind ER, Wessel T, Yuan W (2000) Galantamine in AD: A 6-month randomized, placebocontrolled trial with a 6-month extension. The Galantamine USA-1 study group. Neurology 54, 2261-2268.

[125] Rockwood K, Mintzer J, Truyen L, Wessel T, Wilkinson D (2001) Effects of a flexible Galantamine dose in Alzheimer's disease: A randomised, controlled trial. $J$ Neurol Neurosurg Psychiatry 71, 589-595.

[126] Tariot PN, Solomon PR, Morris JC, Kershaw P, Lilienfeld S, Ding, C (2000) A 5-month, randomized, placebocontrolled trial of Galantamine in AD. The Galantamine USA-10 study group. Neurology 54, 2269-2276.

[127] Wilcock GK, Lilienfeld S, Gaens E (2000) Efficacy and safety of galantamine in patients with mild to moderate Alzheimer's disease: Multicentre randomised controlled trial. Galantamine international-1 study group. BMJ 321, 1445-1449.

[128] Rivastigmine $\left(\right.$ Exelon $\left.^{\circledR}\right)$. http://www.pharma.us.novartis. com/product/pi/pdf/exelon.pdf. Accessed January 8, 2020.
[129] Rivastigmine patch (Exelon Patch ${ }^{\circledR}$ ). http://www.pharma. us.novartis.com/product/pi/pdf/exelonpatch.pdf. Accessed January 8, 2020.

[130] Farlow M, Anand R, Messina J Jr, Hartman R, Veach, J (2000) A 52-week study of the efficacy of rivastigmine in patients with mild to moderately severe Alzheimer's disease. Eur Neurol 44, 236-241.

[131] Winblad B, Cummings J, Andreasen N, Grossberg G, Onofrj M, Sadowsky C, Zechner S, Nagel J, Lane R (2007) A six-month double-blind, randomized, placebocontrolled study of a transdermal patch in Alzheimer's disease-Rivastigmine patch versus capsule. Int J Geriatr Psychiatry 22, 456-467.

[132] Memantine (Namenda $\left.{ }^{\circledR}\right)$. http://www.allergan.com/ assets/pdf/namenda_pi. Accessed January 8, 2020.

[133] Bakchine S, Loft $\mathrm{H}$ (2008) Memantine treatment in patients with mild to moderate Alzheimer's disease: Results of a randomised, double-blind, placebo-controlled 6-month study. J Alzheimers Dis 13, 97-107.

[134] Peskind ER, Potkin SG, Pomara N, Ott BR, Graham SM, Olin JT, McDonald S (2006) Memantine treatment in mild to moderate Alzheimer disease: A 24-week randomized, controlled trial. Am J Geriatr Psychiatry 14, 704-715.

[135] Wang J, Logovinsky V, Hendrix SB, Stanworth SH, Perdomo C, Xu L, Dhadda S, Do I, Rabe M, Luthman J, Cummings J, Satlin A (2016) ADCOMS: A composite clinical outcome for prodromal Alzheimer's disease trials. J Neurol Neurosurg Psychiatry 87, 993-999.

[136] Li DD, Zhang YH, Zhang W, Zhao P (2019) Meta-analysis of randomized controlled trials on the efficacy and safety of donepezil, galantamine, rivastigmine, and memantine for the treatment of Alzheimer's disease. Front Neurosci 13, 472 .

[137] Cummings J, Lee G, Ritter A, Zhong K (2018) Alzheimer's disease drug development pipeline: 2018. Alzheimers Dement (N Y) 4, 195-214.

[138] Cummings J, Lee G, Ritter A, Sabbagh M, Zhong K (2019) Alzheimer's disease drug development pipeline. Alzheimers Dement (N Y) 5, 272-293.

[139] Arndt JW, Qian F, Smith BA, Quan C, Kilambi KP, Bush MW, Walz T, Pepinsky RB, Bussière T, Hamann S, Cameron TO, Weinreb PH (2018) Structural and kinetic basis for the selectivity of Aducanumab for aggregated forms of amyloid- $\beta$. Sci Rep $\mathbf{8}, 6412$.

[140] Sevigny J, Chiao P, Bussière T, Weinreb PH, Williams L, Maier M, Dunstan R, Salloway S, Chen T, Ling Y, O'Gorman J, Qian F, Arastu M, Li M, Chollate S, Brennan MS, Quintero-Monzon O, Scannevin RH, Arnold HM, Engber T, Rhodes K, Ferrero J, Hang Y, Mikulskis A, Grimm J, Hock C, Nitsch RM, Sandrock A (2016) The antibody Aducanumab reduces A $\beta$ plaques in Alzheimer's disease. Nature 537, 50-56.

[141] U.S. National library of medicine. Multiple dose study of Aducanumab (biib037) (recombinant, fully human anti-A $\beta \operatorname{IgG} 1 \mathrm{mAb}$ ) in participants with prodromal or mild Alzheimer's disease (PRIME). https://clinicaltrials. gov/ct2/show/NCT01677572. Accessed January 8, 2020.

[142] U.S. National library of medicine. 221AD301 Phase 3 Study of Aducanumab (BIIB037) in early Alzheimer's disease (ENGAGE). https://clinicaltrials.gov/ct2/show/ NCT02477800. Accessed January 8, 2020.

[143] U.S. National library of medicine. 221AD302 Phase 3 Study of Aducanumab (BIIB037) in Early Alzheimer's Disease (EMERGE). https://clinicaltrials.gov/ct2/show/ NCT02484547. Accessed January 8, 2020. 
[144] http://investors.biogen.com/news-releases/news-releasedetails/biogen-plans-regulatory-filing-aducanumab-alzheimers-disease. Accessed January 8, 2020.

[145] Wiessner C, Wiederhold KH, Tissot AC, Frey P, Danner S, Jacobson LH, Jennings GT, Lüönd R, Ortmann R, Reichwald J, Zurini M, Mir A, Bachmann MF, Staufenbiel M (2011) The second-generation active $A \beta$ immunotherapy CAD106 reduces amyloid accumulation in APP transgenic mice while minimizing potential side effects. $J$ Neurosci 31, 9323-9331.

[146] Neumann U, Ufer M, Jacobson LH, Rouzade-Dominguez ML, Huledal G, Kolly C, Lüönd RM, Machauer R, Veenstra SJ, Hurth K, Rueeger H, Tintelnot-Blomley M, Staufenbiel M, Shimshek DR, Perrot L, Frieauff W, Dubost V, Schiller H, Vogg B, Beltz K, Avrameas A, Kretz S, Pezous N, Rondeau JM, Beckmann N, Hartmann A, Vormfelde S, David OJ, Galli B, Ramos R, Graf A, Lopez Lopez C (2018) The BACE-1 inhibitor CNP520 for pre- vention trials in Alzheimer's disease. EMBO Mol Med 10, e9316.

[147] U.S. National Library of Medicine. A study of CAD106 and CNP520 versus placebo in participants at risk for the onset of clinical symptoms of Alzheimer's disease (Generation S1). https://clinicaltrials.gov/ct2/show/ NCT02565511. Accessed January 8, 2020.

[148] U.S. National Library of Medicine. A study of CNP520 versus placebo in participants at risk for the onset of clinical symptoms of Alzheimer's disease (Generation S2). https://clinicaltrials.gov/ct2/show/NCT03131453. Accessed January 8, 2020.

[149] PR Newswire. https://www.prnewswire.com/news-releases/amgen-novartis-and-banner-alzheimers-institute-discontinue-clinical-research-program-with-bace-inhibitorcnp520-for-alzheimers-prevention-300883758.html. Accessed January 8, 2020. 